\title{
myo-Inositol pentakisphosphates
}

\section{Structure, biological occurrence and phosphorylation to myo-inositol hexakisphosphate}

\author{
Leonard R. STEPHENS, ${ }^{*} \|$ Phillip T. HAWKINS, $\uparrow$ Alison F. STANLEY, $\dagger$ Terry MOORE, $\ddagger$ David R. POYNER, $\dagger$ \\ Peter J. MORRIS, $\ddagger$ Michael R. HANLEY, $\dagger$ Robert R. KAY§ and Robin F. IRVINE* \\ *Biochemistry Department, AFRC, Babraham, Cambridge CB2 4AT, U.K., †MRC Molecular Neurobiology Unit, MRC Centre, \\ Hills Road, Cambridge CB2 2QH, U.K., ‡Department of Biochemistry, University of Cambridge, Tennis Court Road, \\ Cambridge CB2 1QW, U.K., and §MRC Laboratory of Molecular Biology, New Addenbrooke's Site, Hills Road, \\ Cambridge CB2 2QH, U.K.
}

\begin{abstract}
1. Standard and high-performance anion-exchange-chromatographic techniques have been used to purify myo$\left[{ }^{3} \mathrm{H}\right]$ inositol pentakisphosphates from various myo- $\left[{ }^{3} \mathrm{H}\right]$ inositol-prelabelled cells. Slime mould (Dictyostelium discoideum) contained $8 \mu \mathrm{M}$-myo- $\left[{ }^{3} \mathrm{H}\right]$ inositol 1,3,4,5,6-pentakisphosphate, $16 \mu \mathrm{M}$-myo- $\left[{ }^{3} \mathrm{H}\right]$ inositol 1,2,3,4,6-pentakisphosphate and $36 \mu \mathrm{M}-\mathrm{D}-\mathrm{myo}-\left[{ }^{3} \mathrm{H}\right]$ inositol 1,2,4,5,6-pentakisphosphate [calculated intracellular concentrations; Stephens \& Irvine (1990) Nature (London) 346, 580-583]; germinating mung-bean (Phaseolus aureus) seedlings contained both D- and L-myo$\left[{ }^{3} \mathrm{H}\right]$ inositol 1,2,4,5,6-pentakisphosphate (which was characterized by ${ }^{31} \mathbf{P}$ and two-dimensional proton n.m.r.) and D- and/or L-myo- $\left[{ }^{3} \mathrm{H}\right]$ inositol 1,2,3,4,5-pentakisphosphate; HL60 cells contained myo- $\left[{ }^{3} \mathrm{H}\right]$ inositol 1,3,4,5,6-pentakisphosphate (in a 500-fold excess over the other species), myo- $\left[{ }^{3} \mathrm{H}\right]$ inositol 1,2,3,4,6-pentakisphosphate and $\mathrm{D}-$ and/or L-myo- $\left[{ }^{3} \mathrm{H}\right]$ inositol 1,2,4,5,6-pentakisphosphate ; and NG-1 15-401L-C3 cells contained myo- $\left[{ }^{3} \mathrm{H}\right]$ inositol 1,3,4,5,6-pentakisphosphate (in a 100-fold excess over the other species), D- and/or L-myo- $\left[{ }^{3} \mathrm{H}\right]$ inositol 1,2,4,5,6-pentakisphosphate, myo$\left[{ }^{3} \mathrm{H}\right]$ inositol 1,2,3,4,6-pentakisphosphate and $\mathrm{D}$ - and/or L-myo- $\left[{ }^{3} \mathrm{H}\right]$ inositol 1,2,3,4,5-pentakisphosphate. 2. Multiple soluble ATP-dependent myo-inositol pentakisphosphate kinase activities have been detected in slime mould, rat brain and germinating mung-bean seedling homogenates. In slime-mould cytosolic fractions, the three myo-inositol pentakisphosphates that were present in intact slime moulds could be phosphorylated to myo- $\left[{ }^{3} \mathrm{H}\right]$ inositol hexakisphosphate: the relative first-order rate constants for these reactions were, in the order listed above, 1:8:31 respectively (with first-order rate constants in the intact cell of $0.1,0.8$ and $3.1 \mathrm{~s}^{-1}$, assuming a cytosolic protein concentration of $50 \mathrm{mg} / \mathrm{ml}$ ), and the $K_{\mathrm{m}}$ values of the activities for their respective inositol phosphate substrates (in the presence of $5 \mathrm{mM}$ ATP) were $1.6 \mu \mathrm{M}, 3.8 \mu \mathrm{M}$ and $1.4 \mu \mathrm{M}$. At least two forms of myo-inositol pentakisphosphate kinase activity could be resolved from a slime-mould cytosolic fraction by both pharmacological and chromatographic criteria. Rat brain cytosol and a soluble fraction derived from germinating mung-bean seedlings could phosphorylate myo-inositol D/L-1,2,4,5,6-, D/L-1,2,3,4,5-, 1,2,3,4,6- and 1,3,4,5,6-pentakisphosphates to myo-inositol hexakisphosphate: the relative first-order rate constants were 57:27:77:1 respectively for brain cytosol (with first-order rate constants in the intact cell of $0.0041,0.0019$, 0.0056 and $0.000073 \mathrm{~s}^{-1}$ respectively, assuming a cytosolic protein concentration of $50 \mathrm{mg} / \mathrm{ml}$ ) and $1: 11: 12: 33$ respectively for mung-bean cytosol (with first-order rate constants in a supernatant fraction with a protein concentration of $10 \mathrm{mg} / \mathrm{ml}$ of $0.0002,0.0022,0.0024$ and $0.0066 \mathrm{~s}^{-1}$ respectively).
\end{abstract}

\section{INTRODUCTION}

Of the six isomers of $\operatorname{Ins} P_{5}, \operatorname{Ins}(1,3,4,5,6) P_{5}$ was the first to be characterized in biological extracts (Johnson \& Tate, 1969). This Ins $P_{5}$ isomer has since been identified as the major Ins $P_{5}$ in bovine brain and platelets (Phillippy \& Bland, 1988; Mayr, 1988 ), but it was the minor Ins $P_{5}$ in extracts of soya bean (Phillippy \& Bland, 1988). Proven biological functions for Ins $P_{5}$ are few. B. B. Biswas et al. (1978) have proposed that Ins $(1,3,4,5,6) P_{5}$ is the intermediate in both the synthesis and degradation of $\operatorname{Ins} P_{6}$ in mung beans, by serving either as a substrate for, or the product of (in the 'forward direction' by their definition) an Ins $P_{6} /$ ADP phosphotransferase. In erythrocytes of a number of amphibians and the majority of birds Ins $(1,3,4,5,6) P_{5}$ serves as a modulator of the oxygen affinity of haemoglobin (much as 2,3-diphosphoglycerate does in mammals; Bartlett, 1982). The ease with which Ins $(1,3,4,5,6) P_{5}$ can be isolated from avian erythrocytes has resulted in it becoming commercially available; hence it has been tested in more biological assays than any of the other isomers of Ins $P_{5}$. Reports of the ability of Ins $(1,3,4,5,6) P_{5}$ to excite neurons in the brain stems of rats (Vallejo et al., 1987) and potently to inhibit mammalian aldolase A (Koppitz et al., 1986) and Ins(1,3,4,5) $P_{4}$ 3-phosphatase (Hughes \& Shears, 1990) have been published. In contrast with Ins $(1,3,4,5,6) P_{5}$, the lack of availability of the other Ins $P_{5}$ isomers has meant that they have received less attention; as a result, little is known of the specificity of the effects of $\operatorname{Ins}(1,3,4,5,6) P_{5}$ on the various processes described above, and nothing is known of the biological properties of any of the other five Ins $P_{5}$ isomers.

Although Ins $P_{6}$ is the most naturally abundant (in terms of mass in the biosphere) inositol phosphate, and many functions have been ascribed to it (mainly in its capacity as a storage molecule; Williams, 1970), its synthesis is ill-understood. An activity has been purified from mung beans that can transfer a phosphate from ATP to Ins $(1,3,4,5,6) P_{5}$ (see above; S. Biswas et al., 1978), yielding Ins $P_{6}$; however, the ability of a crude homogenate to phosphorylate any of the other $\operatorname{Ins} P_{5}$ isomers was not investigated. More recently it has been reported that a ${ }^{3} \mathrm{H}$ labelled molecule, with the chromatographic properties of an Ins $P_{5}$ (extracted from $\left[{ }^{3} \mathrm{H}\right]$ Ins-prelabelled adrenal glomerulosa cells) could be converted into a $\left[{ }^{3} \mathrm{H}\right] \mathrm{Ins} P_{6}$-like compound when injected into Xenopus oocytes (Ji et al., 1990). It was suggested that an Ins $P_{5}$ kinase activity was responsible for catalysing the reaction, although neither its substrate specificity nor product

\| To whom correspondence and reprint requests should be sent. 
were defined. Some of the metabolic pathways in the slime mould Dictyostelium discoideum that make and break down Ins $P_{6}$ have recently been characterized (Stephens \& Irvine, 1990). Evidence was presented that three Ins $P_{5}$ isomers could be detected in intact amoebae, all of which were substrates for putative $\operatorname{Ins} P_{5}$ hydroxy kinase(s), but only one of which was the precursor de novo of Ins $P_{6}$. The experiments described in the present paper were aimed at establishing in Dictyostelium the specificity and properties of the Ins $P_{5}$ hydroxy kinase (or if indeed there are multiple forms of the enzyme), and whether similar activities can be identified in other plant and animal cells. We also present for the first time some of the detailed strategies and supporting data which enabled the Ins $P_{5}$ isomers in the amoebae to be identified and which were used to characterize the Ins $P_{5}$ isomers found in a number of other cellular systems.

We should note the nomenclature procedure that we have followed here. Under a recent IUPAC suggestion, the abbreviation Ins may be used for D-myo-inositol. This abbreviation is not followed in this paper; here, Ins stands for myo-inositol with no enantiomeric determination. As myo-inositol has a plane of symmetry down the $2 / 5-\mathrm{OH}$ axis, there are two Ins $P_{5}$ isomers which are meso compounds: Ins $(1,3,4,5,6) P_{5}$ and $\operatorname{Ins}(1,2,3,4,6) P_{5}$. However, the other four Ins $P_{5}$ isomers form two enantiomeric pairs. Thus D-Ins $(1,2,4,5,6) P_{5}$ and D-Ins $(2,3,4,5,6) P_{5}$ may be called instead D- and L-Ins $(1,2,4,5,6) P_{5}$ respectively. Similarly, D$\operatorname{Ins}(1,2,3,4,5) P_{5}$ and $\mathrm{D}-\operatorname{Ins}(1,2,3,5,6) P_{5}$ are an enantiomeric pair which may alternatively be called $\mathrm{D}$ - and $\mathrm{L}-\operatorname{Ins}(1,2,3,4,5) P_{5}$ respectively. Because of the emphasis on enantiomeric determinations in parts of this paper, we have used the latter system throughout. It should therefore be noted that D-Ins $(2,3,4,5,6) P_{5}$ and D-Ins $(1,2,3,5,6) P_{5}$ do not appear so named in this paper, but are instead referred to solely by their alternative names, L$\operatorname{Ins}(1,2,4,5,6) P_{5}$ and $\mathrm{L}-\operatorname{Ins}(1,2,3,4,5) P_{5}$ respectively. If the terms Dor L- are used, it is only for compounds whose enantiomeric configuration is known. For uncharacterized samples extracted from biological sources we use the designation D- and/or L-, which emphasizes that the Ins $P_{5}$ in question may be either D- or $\mathrm{L}-$, or a mixture of both in unknown proportions. However, samples generated by symmetrical chemical reactions (for example, non-enzymic phosphorylation or alkaline dephosphorylation) will inevitably be exactly 50:50 mixtures of enantiomers, and the designation $\mathrm{D} / \mathrm{L}$ is used to describe these.

\section{MATERIALS AND METHODS}

\section{Incubation of Dictyostelium with $\left[{ }^{3} \mathbf{H}\right] \mathbf{I n s}$ and $\left[{ }^{32} \mathbf{P}\right] \mathbf{P}_{\mathbf{i}}$}

Dictyostelium discoideum (strain NC4) was co-cultured with Klebsiella aerogenes as described previously (Kay \& Trevan, 1981). Cells were harvested into $20 \mathrm{~mm}-\mathrm{NaCl} / 20 \mathrm{~mm}-\mathrm{KCl} / 1 \mathrm{~mm}-$ $\mathrm{CaCl}_{2} / 10$ mM-Mes ( $\mathrm{pH} \mathrm{6.2,22}{ }^{\circ} \mathrm{C}$ ) and freed from bacteria by differential centrifugation (Kay \& Trevan, 1981). Amoebae harvested from half-cleared plates were incubated with $\left[{ }^{32} \mathrm{P}\right] \mathrm{P}_{\mathrm{i}}$ or $\left[{ }^{3} \mathrm{H}\right] \mathrm{Ins}$ in the salt solution in which they were harvested at $2 \times 10^{7}$ cells $/ \mathrm{ml}$ and shaken at $180 \mathrm{rev} / \mathrm{min}$ on an orbital mixer. Labelling reactions were quenched by pelleting the amoebae by centrifugation $(5 \mathrm{~min}$ at $300 \mathrm{~g})$, aspirating the medium and adding ice-cold $5 \%(\mathrm{v} / \mathrm{v}) \mathrm{HClO}_{4}(2 \mathrm{ml})$. After $5 \mathrm{~min}$ on ice, the acidprecipitated cellular debris was pelleted by centrifugation (benchtop, maximum setting) and the supernatants were neutralized with $2 \mathrm{M}-\mathrm{KOH} / 0.1 \mathrm{M}-\mathrm{Mes} / 25 \mathrm{~mm}$-EDTA (approx. $0.5 \mathrm{ml}$ ) and stored at $-80^{\circ} \mathrm{C}$. The acid extracts were separated on anionexchange h.p.l.c. columns (see below).

\section{Preparation of subcellular fractions from Dictyostelium}

Amoebae harvested from half-cleared plates (see above) were resuspended at $3 \times 10^{8}$ cells $/ \mathrm{ml}$ in $10 \%(\mathrm{v} / \mathrm{v})$ glycerol $/ 10 \mathrm{~mm}$ -
Hepes/1 mM-EGTA/0.1 mM-phenylmethanesulphonyl fluoride (pH 7.5, $4^{\circ} \mathrm{C}$ ), then lysed by forcing them through a filter (Das \& Henderson, 1983). The homogenates produced by filtration were mixed with $0.009 \mathrm{vol}$. of $1 \mathrm{M}$-Hepes (bringing the final overall $\mathrm{pH}$ to 7.0) and dithiothreitol (final concn. $1 \mathrm{mM}$ ). Supernatant fractions were prepared from these homogenates by centrifugation $\left(1 \mathrm{~h}, 100000 \mathrm{~g}, 4^{\circ} \mathrm{C}\right)$, and particulate fractions were prepared by resuspending the membrane pellet to the volume of the original lysate with lysis buffer ( $\mathrm{pH}$ adjusted and dithiothreitol added). Cytosolic and particulate fractions prepared in this way were usually used immediately, although supernatants were successfully stored at $-80^{\circ} \mathrm{C}$ for up to 2 months. To enable assays to be run under first-order conditions with only $5-25 \%$ substrate utilization, cytosolic fractions were diluted into $25 \mathrm{~mm}$-Hepes/1 mM-EGTA/1 mm-dithiothreitol/ $1 \mathrm{mg}$ of $\mathrm{BSA} / \mathrm{ml}\left(\mathrm{pH} 7.0,4^{\circ} \mathrm{C}\right)$.

\section{Development of Dictyostelium}

AX2, an axenic laboratory strain of the cellular slime mould Dictyostelium, was cultured, harvested and developed as described previously (Watts \& Ashworth, 1970; Stephens et al., 1990). Cell lysates for enzyme assays were prepared in two ways: (a) as described by Kay (1979) for the cyclic AMP phosphodiesterase and glycogen phosphorylase assays (essentially $2 \times 10^{7}$ cells were scraped from the solid support, pelleted in a Microfuge, and the supernatant was removed and the pellet was solubilized with $1 \mathrm{ml}$ of lysis buffer); or (b) as described by Stephens \& Irvine (1990) for the $\left[{ }^{3} \mathrm{H}\right] \mathrm{Ins} P_{5}$ hydroxy kinase assays. Essentially, $(3-4) \times 10^{8}$ cells were scraped from the solid support, and samples containing $0.85 \times 10^{8}$ cells were pelleted in a Microfuge, the supernatant was removed and the cells were lysed into $1 \mathrm{ml}$ of lysis buffer. Samples of these lysates were assayed for protein and then diluted to $1 \mathrm{mg}$ of protein/ml with additional lysis buffer, and then diluted again into $25 \mathrm{~mm}$-Hepes/1 mM-EGTA/1 mMdithiothreitol $/ 1 \mathrm{mg}$ of $\mathrm{BSA} / \mathrm{ml}$ before finally assaying the $\left[{ }^{3} \mathrm{H}\right]$ Ins $P_{5}$ hydroxy kinase activities as described above.

Acid extracts were prepared from $4 \times 10^{8}$ cells (one $14 \mathrm{~cm}$ diameter culture plate, three plates for each time point) by scraping the cells into $10 \mathrm{ml}$ of harvesting buffer and then pelleting them by centrifugation, removing the supernatant, adding $1.7 \mathrm{ml}$ of $0.6 \mathrm{M}-\mathrm{HClO}_{4}$, vortex-mixing and standing them on ice. After $5 \mathrm{~min}$ on ice, the acid extracts were mixed with Ins $\left[{ }^{32} \mathrm{P}\right] P_{6}$ (900 c.p.m., prepared from $\left[{ }^{32} \mathrm{P}\right] \mathrm{P}_{\mathrm{i}}$-labelled mung beans and containing less than $1 \mathrm{nmol}$ of total phosphorus), then centrifuged for $5 \mathrm{~min}$ (at the maximum setting of a bench-top centrifuge), and the supernatant was neutralized with $2 \mathrm{M}$ $\mathrm{KOH} / 0.1 \mathrm{M}$-Mes/25 mM-EDTA. The $\mathrm{KClO}_{4}$ precipitate was compacted by centrifugation, and the supernatant was filtered and applied to a weak anion-exchange h.p.l.c. column (Partisphere, $25 \mathrm{~cm})$. The column was eluted with a gradient ( $\mathrm{A}=$ water, $\mathrm{B}=2.5 \mathrm{M}-\mathrm{NaH}_{2} \mathrm{PO}_{4}, \mathrm{pH} 3.8$ ) following the pattern: $0 \mathrm{~min}, 0 \% \mathrm{~B} ; 15 \mathrm{~min}, 25 \% \mathrm{~B} ; 50 \mathrm{~min}, 67 \% \mathrm{~B} ; 51 \mathrm{~min}, 100 \% \mathrm{~B}$; $56 \mathrm{~min}, 100 \% \mathrm{~B}(1.0 \mathrm{ml} / \mathrm{min})$. The quality of the chromatography obtained was routinely checked by monitoring the absorbance (at $254 \mathrm{~nm}$ ) of the eluate; fractions were collected every $1 \mathrm{~min}$ and counted for ${ }^{32} \mathrm{P}$ by Čerenkov counting techniques. Those fractions containing ${ }^{32} \mathrm{P}$ were pooled, desalted (Stephens \& Downes, 1990) and assayed for both free inorganic phosphorus and total phosphorus (Baginski et al., 1967; Bartlett, 1959 , as modified by Galliard et al., 1965). The Ins $P_{6}$ concentration in the original extracts was calculated by assuming an inositol/phosphorus ratio of $1: 6$ and using the amount of ${ }^{32} \mathrm{P}$ finally recovered in the fractions assayed for phosphorus as an estimate of the recovery of Ins $P_{6}$ through the extraction, purification and desalting steps (recoveries ranged from 55 to $80 \%$ ). The data were finally expressed in terms of the amount of Ins $P_{6}$ 
per $\mathrm{mg}$ of cellular protein by solubilizing the original $\mathrm{HClO}_{4}^{-}$ precipitated cell debris in warm $1 \mathrm{M}-\mathrm{NaOH}$ and assaying for protein with BSA as a standard (Bradford, 1976).

\section{Preparation of a soluble fraction from mung-bean seedlings}

Mung beans were cleaned with $70 \%$ ethanol and then with distilled water and allowed to germinate in distilled water (approx. $1 \mathrm{~g}$ of mung beans to $10 \mathrm{ml}$ of water) in the dark at room temperature. Mung-bean homogenates were prepared by germinating mung beans in water, then decoating and disrupting them ( $10 \mathrm{~g}$ wet $w \mathrm{t}$.$) , first in a large rotating-blade homogenizer$ $(30 \mathrm{~s})$ and then with a Polytron (15 s) into $10 \mathrm{ml}$ of $25 \mathrm{~mm}$ Hepes/1 mM-EGTA/1 mM-dithiothreitol (pH 7.0, $\left.4{ }^{\circ} \mathrm{C}\right)$. The homogenate was centrifuged $\left(100000 \mathrm{~g}, 1 \mathrm{~h}, 4^{\circ} \mathrm{C}\right)$ and the supernatant was used immediately.

\section{Mammalian cell culture}

NG-115-401L-C3 cells were cultured and labelled with $\left[{ }^{3} \mathrm{H}\right] \mathrm{Ins}$ for 3 days in $35 \mathrm{~mm}$-diam. Petri dishes $\left(1 \mathrm{mCi}\right.$ of $\left.\left[{ }^{3} \mathrm{H}\right] \mathrm{Ins} / \mathrm{ml}\right)$ in a medium of inositol-free Dulbecco's modified Eagle medium with $10 \%(\mathrm{v} / \mathrm{v})$ dialysed foetal-calf serum, as described previously (Jackson et al., 1987). Acid extracts were prepared from $\left[{ }^{3} \mathrm{H}\right]$ Ins-prelabelled cells by sequentially aspirating the medium, adding ice-cold $5 \%(\mathrm{v} / \mathrm{v}) \mathrm{HClO}_{4}(2 \mathrm{ml})$, scraping the cells from the dish, pelleting the precipitated cellular debris by centrifugation and neutralizing the supernatant with $2 \mathrm{M}-\mathrm{KOH} / 0.1 \mathrm{M}-$ Mes/25 mM-EDTA.

HL60 cells were cultured in inositol-free RPMI medium (Gibco) with $10 \%$ foetal-calf serum either with or without $\left[{ }^{3} \mathrm{H}\right]$ Ins (as described in French et al., 1988). $\left[{ }^{3} \mathrm{H}\right]$ Ins-prelabelled cells (after 4 days in the presence of $\left[{ }^{3} \mathrm{H}\right]$ Ins) were pelleted by centrifugation, their medium was aspirated and ice-cold $5 \%$ $\mathrm{HClO}_{4}$ was added $(2 \mathrm{ml})$. After mixing, the cellular debris was pelleted by centrifugation and the supernatant was neutralized with $2 \mathrm{M}-\mathrm{KOH} / 0.1 \mathrm{M}-\mathrm{Mes} / 25$ mM-EDTA.

\section{Preparation of subcellular fractions from rat brain}

Rat brain homogenates, particulate and cytosol fractions were prepared as described in Stephens et al. $(1988 b)$. One rat brain was routinely homogenized in $5 \mathrm{ml}$ of buffer and the homogenate centrifuged at $100000 \mathrm{~g}$ for $45 \mathrm{~min}$ to produce a crude cytosol fraction and a membrane pellet. The membrane pellet was resuspended to the original volume of the homogenate with fresh buffer to yield a particulate fraction.

\section{Resolution of $\operatorname{Ins} \boldsymbol{P}_{5}$ isomers by anion-exchange h.p.l.c.}

Mixtures of, or individual, radiolabelled Ins $P_{5}$ isomers (prepared as described below) were separated on either weak or strong anion-exchange h.p.l.c. columns (Whatman). Partisphere WAX columns [which had been pre-equilibrated with buffer $\mathbf{B}$ : $0.5 \mathrm{M}-\left(\mathrm{NH}_{4}\right)_{2} \mathrm{HPO}_{4}$, adjusted to $\mathrm{pH} 3.2$ with $\left.\mathrm{H}_{3} \mathrm{PO}_{4}, 22^{\circ} \mathrm{C}\right]$ were eluted with a gradient based on water and buffer $\mathrm{B}$ (see above) to the pattern $0 \mathrm{~min} 0 \% \mathrm{~B}, 1 \mathrm{~min} 40 \% \mathrm{~B}, 60 \mathrm{~min} 70 \% \mathrm{~B}, 61 \mathrm{~min}$ $100 \%$ B, $70 \mathrm{~min} 100 \% \mathrm{~B}$, at a flow rate of $1 \mathrm{ml} / \mathrm{min}$. Fractions were collected and counted for radioactivity by standard liquidscintillation counting techniques. Partisil 10SAX or Partisphere 5SAX columns were pre-equilibrated and eluted with $2.5 \mathrm{M}$ $\mathrm{NaH}_{2} \mathrm{PO}_{4}\left(\mathrm{pH} 3.75\right.$ with $\mathrm{NaOH}, 22^{\circ} \mathrm{C}$ ) or $1.25 \mathrm{M}-\left(\mathrm{NH}_{4}\right)_{2} \mathrm{HPO}_{4}$ (pH 3.8 with $\mathrm{H}_{3} \mathrm{PO}_{4}, 22^{\circ} \mathrm{C}$ ) respectively. The pattern of phosphate gradient employed with these columns was identical with that used with the WAX column described above.

\section{Resolution of $\operatorname{Ins} P_{5}$ and $\operatorname{Ins} P_{6}$ by batch elution of anion- exchange resin}

For this, $12 \mathrm{~cm} \times 0.6 \mathrm{~cm}$ columns of Bio-Rad AG $1 \times 8$ (200-400 mesh; chloride form) were used (some columns were capped with a $5 \mathrm{~mm}$-deep layer of $\mathrm{HCl}$-washed sand; this resulted in a marginal decrease in the amount of the Ins $P_{5}$ isomers eluted in the Ins $P_{6}$ fractions and significantly prolonged the life of the columns by protecting against dehydration). Samples were loaded in $5 \mathrm{ml}$ of water and washed on with a further $5 \mathrm{ml}$ of water. Ins $P_{5}$ isomers were eluted as follows: $\left[{ }^{3} \mathrm{H}\right] \operatorname{Ins}(1,2,3,4,6) P_{5}$ and $\mathrm{D} / \mathrm{L}-\left[{ }^{3} \mathrm{H}\right] \operatorname{Ins}(1,2,3,4,5) P_{5}$ with $5 \times 10 \mathrm{ml}$ of $0.65 \mathrm{M}-\mathrm{HCl}$; D/L- $\left[{ }^{3} \mathrm{H}\right] \operatorname{Ins}(1,2,4,5,6) P_{5}$ with $6 \times 10 \mathrm{ml}$ of $0.65 \mathrm{M}-\mathrm{HCl}$; and $\left[{ }^{3} \mathrm{H}\right] \operatorname{Ins}(1,3,4,5,6) P_{5}$ with $8 \times 10 \mathrm{ml}$ of $0.63 \mathrm{M}-\mathrm{HCl}$. Ins $P_{6}$ was eluted with $2 \times 10 \mathrm{ml}$ of $1.5 \mathrm{M}-\mathrm{HCl}$. Representative profiles are shown in Fig. 1. The spill-over of Ins $P_{5}$ into $\operatorname{Ins} P_{6}$ fractions was always less than $0.5 \%$, and the loss of Ins $P_{6}$ into Ins $P_{5}$ fractions (which was assessed in most experiments by the addition of a portion of Ins $\left[{ }^{32} \mathrm{P}\right] P_{6}$ to each sample before application to the resin columns) was at worst $1.5 \%$. The $10 \mathrm{ml}$ fractions were all mixed with $10 \mathrm{ml}$ of either Packard 299 or Zinsser Hi-salt scintillation fluid and counted for ${ }^{3} \mathrm{H}$ and/or ${ }^{32} \mathrm{P}$ radioactivity by standard dual-label liquid-scintillation counting techniques.

\section{Preparation of standard $\operatorname{Ins} P_{5}$ isomers and $\operatorname{Ins} P_{6}$}

Preparation of ${ }^{3} \mathrm{H}$ - or ${ }^{32} \mathrm{P}$-labelled $\operatorname{Ins} P_{5}$ isomers and $\operatorname{Ins} P_{6}$ from mung beans. To prepare radiolabelled $D$ - and/or L$\operatorname{Ins}(1,2,3,4,5) P_{5}$, D- and/or L-Ins $(1,2,4,5,6) P_{5}$ and $\operatorname{Ins} P_{6},\left[{ }^{3} \mathrm{H}\right] \operatorname{Ins}$ or $\left[{ }^{32} \mathrm{P}\right] \mathrm{P}_{1}$ was added to the distilled water in which mung beans were germinated (see above and the Results section; typically, $0.5 \mathrm{mCi}$ of $\left[{ }^{3} \mathrm{H}\right]$ Ins or $\left[{ }^{32} \mathrm{P}\right] \mathrm{P}_{1}$ and a single mung bean were used). After 55-60 h the mung beans were removed from the residual water and homogenized with a glass-on-glass (studded pestle) hand homogenizer in $2 \mathrm{ml}$ of ice-cold $5 \% \mathrm{HClO}_{4}$. The homogenized tissue was pelleted by centrifugation and the supernatant neutralized with octylamine/Freon $(1: 1, \mathrm{v} / \mathrm{v}$; Sharpes \& McCarl, 1982) before the addition of $50 \mu \mathrm{l}$ of $0.1 \mathrm{M}$ EDTA. Radiolabelled compounds were purified from these extracts by h.p.l.c. (see above).

Preparation of Ins $\left[{ }^{32} \mathrm{P}\right](1,3,4,5,6) P_{5}$. Ins $\left[{ }^{32} \mathrm{P}\right](1,3,4,5,6) P_{5}$ was prepared from $\left[{ }^{32} \mathrm{P}\right] \mathrm{P}_{1}$-labelled avian erythrocytes precisely as described previously (Stephens et al., 1988a,b).

Preparation of high-specific-radioactivity $\left[{ }^{3} \mathrm{H}\right] \mathrm{Ins} \boldsymbol{P}_{6}$ and $\left[{ }^{3} \mathbf{H}\right]$ Ins $\boldsymbol{P}_{5}$ isomers. This was done by phosphorylation of $\left[{ }^{3} \mathrm{H}\right] \mathrm{Ins}$ as described previously (Cosgrove, 1980), except that highspecific-radioactivity $\left[{ }^{3} \mathrm{H}\right] \mathrm{Ins}(80-120 \mathrm{Ci} / \mathrm{mmol}$; Amersham) was included in the reaction mixture without additional carrier and the quantities of the reagents employed were substantially decreased (Hawkins et al., 1990). After the reaction was complete, the sample was neutralized, diluted and the $\left[{ }^{3} \mathrm{H}\right]$ inositol polyphosphates were isolated by ion-exchange chromatography on an AG-1 (formate form) resin column and desalted by freezedrying as described previously (Hawkins et al., 1990).

$\left[{ }^{3} \mathrm{H}\right]$ Ins $P_{5}$ isomers and $\left[{ }^{3} \mathrm{H}\right]$ Ins $P_{6}$ were purified from the mixture by anion-exchange h.p.l.c. The sample was initially applied to a Partisil 10SAX column (eluted as described above) and the $\left[{ }^{3} \mathrm{H}\right]$ Ins $P_{6}$ peak (identified by its time of elution compared with that of authentic Ins $P_{6}$ under identical circumstances or by inclusion of internal [ $\left.{ }^{32} \mathrm{P}\right] \mathrm{Ins} \boldsymbol{P}_{6}$ ) was collected, desalted, re-applied to a Partisil 10SAX column and then eluted, collected and desalted again. $\left[{ }^{3} \mathrm{H}\right]$ Ins $P_{5}$ isomers were usually eluted in three major peaks; only the fractions containing the highest concentrations of ${ }^{3} \mathrm{H}$ in each peak were saved and desalted (corresponding to roughly $80 \%$ of the total ${ }^{3} \mathrm{H}$ in the peaks). The $\left[{ }^{3} \mathrm{H}\right] \mathrm{Ins} P_{5}$ isomers were each re-applied to a Partisphere WAX h.p.l.c. column and eluted as described above. The two $\left[{ }^{3} \mathrm{H}\right] \mathrm{Ins} P_{5}$ peaks which were eluted first from the Partisil 10SAX column were each eluted as single major peaks (containing $85-90 \%$ of the ${ }^{3} \mathrm{H}$ recovered), and were collected and desalted; the third 

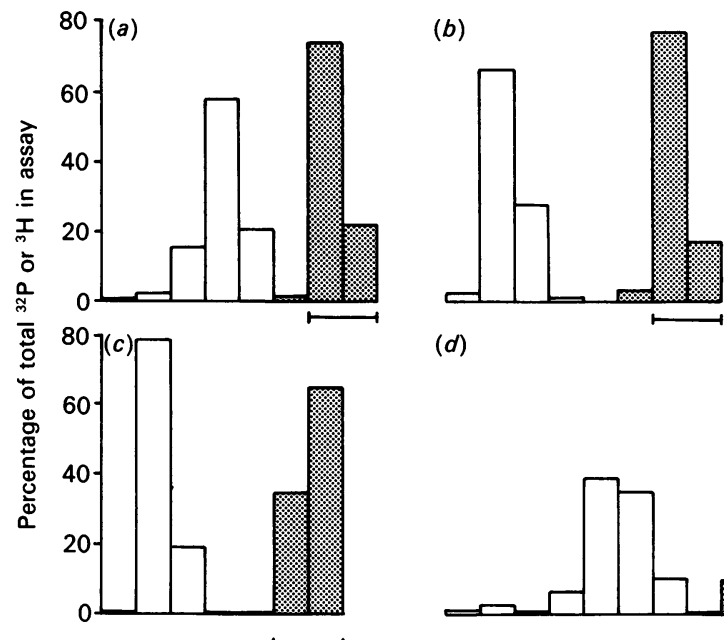

(d)

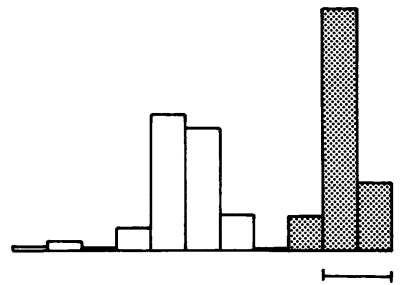

Fig. 1. Separation of $\left[{ }^{3} \mathrm{H}\right] \mathrm{Ins} P_{5} \mathrm{~s}$ from $\left[{ }^{3} \mathrm{H}\right] \mathrm{Ins} P_{6}$ by batch elution from open-topped anion-exchange resin columns

Samples (20000 d.p.m.) of D/L- $\left[{ }^{3} \mathrm{H}\right] \operatorname{Ins}(1,2,4,5,6) P_{5} \quad(a)$, D/L$\left[{ }^{3} \mathrm{H}\right] \operatorname{Ins}(1,2,3,4,5) P_{5} \quad(b), \quad\left[{ }^{3} \mathrm{H}\right] \operatorname{Ins}(1,2,3,4,6) P_{5} \quad(c)$ or $\left[{ }^{3} \mathrm{H}\right]$ Ins$(1,3,4,5,6) P_{5}(d)$ were mixed with 5000 d.p.m. of $\operatorname{Ins}\left[{ }^{32} \mathrm{P}\right] P_{6}$ and applied to $12 \mathrm{~cm} \times 0.6 \mathrm{~cm}$ columns of Bio-Rad AG $1 \times 8 \quad 200-400$ resin (chloride form) and then eluted with sequential $10 \mathrm{ml}$ batches of $0.65 \mathrm{M}-\mathrm{HCl}(a-c)$ or $0.63 \mathrm{M}-\mathrm{HCl}(d)$ followed by two $10 \mathrm{ml}$ batches of $1.5 \mathrm{M}-\mathrm{HCl}$ (marked with a horizontal line). The percentage of the total ${ }^{3} \mathrm{H}$ and ${ }^{32} \mathrm{P}$ (d.p.m.) eluted from the column in each $10 \mathrm{ml}$ batch is shown in the diagram as a series of open bars and stippled bars respectively (the first batch at the extreme left). The results are typical of many hundreds of independently eluted columns. This quality of chromatography was maintained for at least 20-25 independent separations on a single column.

peak was eluted as two well-resolved peaks of ${ }^{3} \mathrm{H}$, which were independently collected and desalted. The identities of the four species of $\left[{ }^{3} \mathrm{H}\right] \mathrm{Ins} P_{5}$ purified after phosphorylation of ${ }^{3} \mathrm{H}[\mathrm{Ins}]$ were confirmed by co-injecting them with ${ }^{32} \mathrm{P}$-labelled standard Ins $P_{5}$ isomers (see below and above for preparation). Typically ${ }^{15-20 \%}$ of the starting ${ }^{3} \mathrm{H}$ would be recovered as pure $\left[{ }^{3} \mathrm{H}\right] \mathrm{Ins} P_{6}$ and $10-12 \%$ as pure $\left[{ }^{3} \mathrm{H}\right] \operatorname{Ins} P_{5}$ isomers. Prepared in this way, $\left[{ }^{3} \mathrm{H}\right] \operatorname{Ins}(1,3,4,5,6) P_{5}$ and $\left[{ }^{3} \mathrm{H}\right] \operatorname{Ins}(1,2,3,4,6) P_{5}$ are radiochemically pure, whereas $\mathrm{D} / \mathrm{L}-\left[{ }^{3} \mathrm{H}\right] \operatorname{Ins}(1,2,3,4,5) P_{5}$ and $\mathrm{D} / \mathrm{L}-\left[{ }^{3} \mathrm{H}\right] \mathrm{Ins}$ $(1,2,4,5,6) P_{5}$ are each racemic mixtures.

Preparation of $\left[{ }^{32} \mathrm{P}\right]-$ or $\left[{ }^{3} \mathrm{H}\right]-$ Ins $\boldsymbol{P}_{5}$ isomers by dephosphorylation of $\left[{ }^{32} \mathrm{P}\right]-$ or $\left[{ }^{3} \mathbf{H}\right]$-Ins $P_{6}$. $\left[{ }^{32} \mathrm{P}\right]-$ or $\left[{ }^{3} \mathrm{H}\right]$-Ins $P_{5}$ isomers were prepared by alkaline hydrolysis of $\left[{ }^{32} \mathrm{P}\right]-$ or $\left[{ }^{3} \mathrm{H}\right]-\mathrm{Ins} P_{6}$ as described by Phillippy et al. (1987). Essentially, h.p.l.c.-pure $\operatorname{Ins} P_{6}$ (either ${ }^{3} \mathrm{H}$ or ${ }^{32} \mathrm{P}$-labelled) was dissolved in $0.5 \mathrm{ml}$ of $50 \mathrm{mM}-\mathrm{Na}_{2} \mathrm{HPO}_{4}$ (pH 10.5 with $\mathrm{NaOH}$ ) and then autoclaved $\left(121^{\circ} \mathrm{C}\right)$ for $3 \mathrm{~h}$. After autoclaving, the sample was cooled, diluted to $2.5 \mathrm{ml}$ and its $\mathrm{pH}$ adjusted to 7.0 with formic acid. Ins $P_{5}$ isomers were resolved from this mixture by anion-exchange h.p.l.c. as described above (first on a Partisphere SAX column and then on a Partisphere WAX column). As with Ins $P_{5}$ isomers obtained by phosphorylation of Ins (above), $\operatorname{Ins}(1,3,4,5,6) P_{5}$ and $\operatorname{Ins}(1,2,3,4,6) P_{5}$ can be obtained pure by this method, but $\mathrm{D} / \mathrm{L}-\operatorname{Ins}(1,2,4,5,6) P_{5}$ and $\mathrm{D} / \mathrm{L}-$ Ins $(1,2,3,4,5) P_{5}$ are both obtained as racemic mixtures.

D- $\left[{ }^{3} \mathrm{H}\right] \operatorname{Ins}(1,2,4,5,6) P_{5}$ (as characterized by Irving \& Cosgrove, 1972) was also prepared from $\left[{ }^{3} \mathrm{H}\right] \mathrm{Ins} P_{6}$ by dephosphorylation with a commercially available fungal phytase (Aspergillus phytase; Sigma). Optimal yields of $\operatorname{Ins} P_{5}$ were obtained when approx. $10-15 \%$ of $\operatorname{Ins} P_{6}$ phosphorus had been released as $P_{i}$. Under first-order conditions (with respect to Ins $P_{6}$ ), incubation of Ins $P_{6}$ with 0.0008 unit (units defined by Sigma) of Aspergillus phytase $/ \mathrm{ml}$ in $20 \mathrm{~mm}$-acetic acid (pH 5.0 with $\mathrm{NaOH}$, $\left.37{ }^{\circ} \mathrm{C}\right) / 1 \mathrm{mg}$ of BSA $/ \mathrm{ml}$ resulted in $10 \%$ of the starting Ins $P_{6}$ being dephosphorylated in $60 \mathrm{~min}$ at $37^{\circ} \mathrm{C}$. The assays were quenched with $\mathrm{HClO}_{4}$ (final concn. $5 \%$ ), precipitated protein was pelleted by centrifugation and the supernatant neutralized with $2 \mathrm{M}-\mathrm{KOH} / 0.1 \mathrm{M}-\mathrm{Mes} / 20 \mathrm{mM}-\mathrm{EDTA}$. The reaction products were resolved by h.p.l.c. and the fractions containing the major Ins $P_{5}$ were pooled and desalted.

Commercially available wheat-bran phytase was used to prepare ${ }^{3} \mathrm{H}$ - and ${ }^{32} \mathrm{P}$-labelled D-Ins $(1,2,3,5,6) P_{5}$ from $\left[{ }^{3} \mathrm{H}\right]-$ or $\left[{ }^{32} \mathrm{P}\right]-$ Ins $P_{6}$ (Tomlinson \& Ballou, $1961 ;$ Lim \& Tate, 1973). Assays contained $\left[{ }^{3} \mathrm{H}\right]-$ or $\left[{ }^{32} \mathrm{P}\right]-$ Ins $P_{6}$ (final concentrations were typically in the $10 \mathrm{nM}-10 \mu \mathrm{M}$ range), 0.0006 unit of phytase $/ \mathrm{ml}, 1 \mathrm{mg}$ of $\mathrm{BSA} / \mathrm{ml}$ and $20 \mathrm{~mm}$-acetic acid (pH 5.0 with $\mathrm{NaOH}, 37^{\circ} \mathrm{C}$ ). After $60 \mathrm{~min}$ at $37^{\circ} \mathrm{C}$ the assays were quenched and the reaction products resolved by h.p.l.c. as described above for the products of fungal phytase attack on Ins $P_{6} ; 8-15 \%$ of the starting material (for $\left[{ }^{3} \mathrm{H}\right] \operatorname{Ins} P_{6}$ ) was typically recovered as $\operatorname{Ins} P_{5}$.

Preparation of large quantities of unlabelled $\operatorname{Ins} P_{5}$ isomers and Ins $\boldsymbol{P}_{6}$. Ins $\boldsymbol{P}_{6}$ was obtained as its barium salt from germinating mung beans as a by-product of the purification of Ins $P_{5}$ isomers for n.m.r. analysis (see below). Ins $P_{6}$ barium salt was converted into the sodium salt as described below [a 60 -fold molar excess of Bio-Rad AG50 $\left(\mathrm{H}^{+}\right.$form) was initially used to convert the Ins $P_{6}$ into its acid form]. Ins $P_{6}$ was also purified from commercially available Ins $P_{6}$ preparations (Sigma) by chromatography on a column of Bio-Rad AG $1 \times 8200-400$ anionexchange resin (chloride form) as described previously (Cosgrove, 1969).

D/L-Ins $(1,2,3,4,5) P_{5}, \mathrm{D} / \mathrm{L}-\operatorname{Ins}(1,2,4,5,6) P_{5}$, Ins $(1,2,3,4,6) P_{5}$ and Ins $(1,3,4,5,6) P_{5}$ were purified from an alkaline digest of Ins $P_{6}$ essentially as described by Cosgrove (1969). Sodium phytate $(5 \mathrm{~g}$; Sigma) was dissolved in $100 \mathrm{ml}$ of water and the $\mathrm{pH}$ was adjusted to 10.0 with $\mathrm{HCl}$. Approx. $2 \times 10^{6}$ d.p.m. of $\left[{ }^{32} \mathrm{P}\right] \mathrm{Ins} P_{6}$ (prepared from ${ }^{32} \mathrm{P}$-labelled mung beans; see above) was added to act as a marker for the presence of inositol phosphates in subsequent steps. The sample was autoclaved at $120^{\circ} \mathrm{C}$ for approx. $60 \mathrm{~min}$. The sample was then diluted to $150 \mathrm{ml}$ with water and the $\mathrm{pH}$ adjusted to 7.0 with $\mathrm{HCl}$. The sample was separated on a $60 \mathrm{~cm} \times 2 \mathrm{~cm}$ column of Bio-Rad AG $1 \times 8$ (200-400 mesh; chloride form) by using an approximately linear gradient formed by the progressive mixing of 2.0 litres of $0.3 \mathrm{M}$ $\mathrm{HCl}$ with 2.0 litres of $1.5 \mathrm{M}-\mathrm{HCl}$. The initial flow rate was approx. $110 \mathrm{ml} / \mathrm{h}$ and fractions were collected every $3 \mathrm{~min}$. The fractions were analysed for the presence of inositol phosphates by measuring their ${ }^{32} \mathrm{P}$ content (Čerenkov radiation). The fractions corresponding to two broad Ins $P_{5}$ peaks (Cosgrove, 1969) were combined and the $\mathrm{pH}$ was adjusted to 5.0 with $\mathrm{Ba}(\mathrm{OH})_{2}$. The barium-Ins $P_{5}$ precipitate was allowed to settle under gravity and washed with water. The first-eluted Ins $P_{5}$ peak consists of a mixture of $\operatorname{Ins}(1,2,3,4,6) P_{5}$ and $\mathrm{D} / \mathrm{L}-\operatorname{Ins}(1,2,3,4,5) P_{5}$, and the second-eluted Ins $P_{5}$ peak consists of a mixture of $\operatorname{Ins}(1,3,4,5,6) P_{5}$ and $\mathrm{D} / \mathrm{L}-\mathrm{Ins}(1,2,4,5,6) P_{5}$ (Cosgrove, 1969). These two samples were further resolved by chromatography on an identical AGl (chloride form) column (see above) by isocratic elution with $0.48 \mathrm{M}-\mathrm{HCl}$ (Cosgrove, 1969). Each Ins $P_{5}$ isomer was finally obtained in $>90 \%$ purity by three successive rounds of chromatography, with isocratic elution with $0.48 \mathrm{M}-\mathrm{HCl}$ in each case. The final washed barium salts of $\operatorname{Ins} P_{5}$ isomers were converted into the sodium salts by treatment with a 60 -fold molar excess of Bio-Rad AG50 $\left(\mathrm{H}^{+}\right.$form) resin and then neutralization with $\mathrm{NaOH}$.

Ins $(1,3,4,5,6) P_{5}$ was also purified by h.p.l.c. with a preparativescale Partisil 10-SAX h.p.l.c. column (the conditions used with analytical 10-SAX columns were scaled up) from commercially available preparations of Ins $(1,3,4,5,6) P_{5}$ (Calbiochem). 

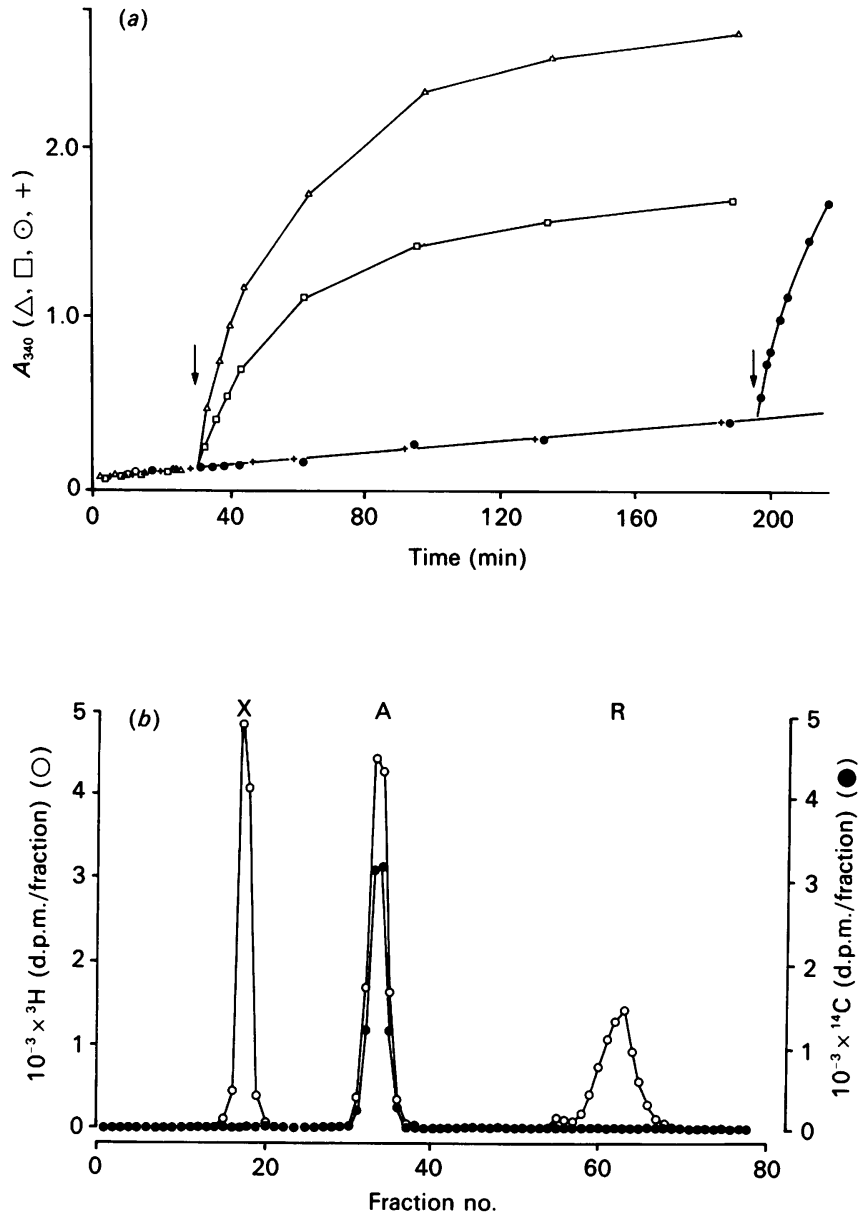

Fig. 2. Oxidation of L- but not D-arabitol by L-iditol dehydrogenase from yeast

(a) Four $1 \mathrm{ml}$ quartz cuvettes, containing $950 \mu \mathrm{l}$ of $100 \mathrm{mM}$-Tris. $\mathrm{HCl}$, $20 \mathrm{mM}-\beta-\mathrm{NAD}^{+}$and 9.5 units of $\mathrm{L}$-iditol dehydrogenase $/ \mathrm{ml}(\mathrm{pH} 8.3$ ), were equilibrated at $25^{\circ} \mathrm{C}$. The $A_{340}$ of each cuvette was monitored periodically. After $30 \mathrm{~min}, 50 \mu \mathrm{l}$ of D-arabitol (+, final concn. $500 \mu \mathrm{M})$, L-arabitol ( $\triangle$, final concn. $1 \mathrm{mM}$; $\square$, final concn. $500 \mu \mathrm{M}$ ), final concn.) or water $(+)$ was added to the cuvettes and mixed. After $200 \mathrm{~min}$, a further $5 \mu \mathrm{l}$ of L-arabitol (final concn. $1 \mathrm{mM}$ ) was added to the cuvette to which water had initially been added $(\odot)$. Only approx. $50 \%$ (range $30-65 \%$ ) of the L-arabitol preparations appeared to be oxidized. This appeared to result from the oxidation process achieving equilibrium under the conditions of the assay, because addition of fresh substrate to a blank assay that had been incubated for $200 \mathrm{~min}(\odot)$ resulted in an initial rate of oxidation that was $93 \%$ of that obtained after $30 \mathrm{~min}$ of incubation. Furthermore, if the products that had accumulated after $2 \mathrm{~h}$ of incubation were purified and incubated with L-iditol dehydrogenase for a second time, then approx. $50 \%$ of the $\mathrm{L}$-arabitol that had remained was again oxidized and the xylulose and ribulose that had remained (see below) generated some arabitol on incubation with L-iditol dehydrogenase. (b) An assay identical with that described in $(a)$ above ( $\square$ ), except that it contained D- $\left[{ }^{14} \mathrm{C}\right]$ arabitol and L- $\left[{ }^{3} \mathrm{H}\right]$ arabitol, was quenched by boiling for 120 min after the addition of the substrate mixture. The sample was processed precisely as described previously (Stephens et al., 1988a) and applied to a cation-exchange resin column in the $\mathrm{Pb}^{2+}$ form (see Stephens et al., 1989). Fractions were collected every $1 \mathrm{~min}(0.2 \mathrm{ml})$ and counted for ${ }^{3} \mathrm{H}$ and ${ }^{14} \mathrm{C}$ radioactivity by standard dual-label liquid-scintillation-counting techniques; $85 \%$ of the ${ }^{14} \mathrm{C}$ and $60 \%$ of the ${ }^{3} \mathrm{H}$ was recovered. The elution positions of xylulose $(X)$, arabitol $(A)$ and ribulose (R) standards in a parallel run are marked (pure solutions of arabitol, ribulose and xylulose were independently injected and their progress through the system was monitored with an on-line differential refractomer, as described by Stephens et al., 1988a). The elution times of the standards are corrected for the lag between the refractometer and fraction collector.
Inositol phosphates were stored either dry or in aqueous solution $\left(\mathrm{pH} \mathrm{7.0)}\right.$ at $-20^{\circ} \mathrm{C}$.

\section{N.m.r. analysis}

To prepare large quantities of Ins $P_{5}$ for n.m.r. analysis, $25 \mathrm{~g}$ of mung beans were germinated for $60 \mathrm{~h}$ (as described above) and then homogenized in ice-cold $5 \% \mathrm{HClO}_{4}$ with two $10 \mathrm{~s}$ bursts in a rotating-blade homogenizer. The debris was pelleted by centrifugation $\left(5000 \mathrm{~g}, 10 \mathrm{~min}, 4^{\circ} \mathrm{C}\right)$ and the $\mathrm{pH}$ of the supernatant was adjusted to 6.0 with $\mathrm{Ba}(\mathrm{OH})_{2}$. The precipitate was collected by centrifugation, and the supernatant was discarded, replaced with a similar volume of water, mixed and centrifuged again. The washed precipitate was mixed with $20 \mathrm{ml}$ of Bio-Rad AG-50 resin ( $\mathrm{H}^{+}$form). After standing at $4{ }^{\circ} \mathrm{C}$ for $60 \mathrm{~min}$, the resin was mixed with $200 \mathrm{ml}$ of water and separated from the liquid phase by filtration through a glass sinter. The $\mathrm{pH}$ of the filtrate was adjusted to 7.0 with $\mathrm{NaOH}$. A total of $0.76 \mathrm{mmol}$ of phosphorus was recovered at this point. The sample was mixed with a defined collection of $\left.{ }^{32} \mathrm{P}\right] \mathrm{Ins} P_{4} \mathrm{~s}$, $\left[{ }^{32} \mathrm{P}\right] \mathrm{Ins} P_{5}$ s and $\left[{ }^{32} \mathrm{P}\right] \mathrm{Ins} P_{6}$ derived from a ${ }^{32} \mathrm{P}$-labelled mung-bean preparation (see above and below) and applied to a $62 \mathrm{~cm} \times 2 \mathrm{~cm}$ column of Bio-Rad AG $1 \times 8$ (200-400 mesh; chloride form) at $2.5 \mathrm{ml} / \mathrm{min}$. The column was eluted with a gradient which started at $0 \mathrm{~min}$ at $0.12 \mathrm{M}-\mathrm{HCl}$, and rose linearly over 4 litres to $1.2 \mathrm{M}-\mathrm{HCl}$, at which point the eluent was switched to $2 \mathrm{M}-\mathrm{HCl}$ for a further 1.8 litres; $24 \mathrm{ml}$ fractions were collected throughout. As fractions emerged from the column they were counted for ${ }^{32} \mathrm{P}$ radioactivity and stored at $4{ }^{\circ} \mathrm{C}$ in batches of $25 .{ }^{32} \mathrm{P}$-containing fractions were pooled and precipitated with $\mathrm{Ba}(\mathrm{OH})_{2}$ as described above. The more retained Ins $P_{5}$ peak was converted into its acid form, neutralized with $\mathrm{NaOH}$ and quantified by phosphate assay ( $20.6 \mu \mathrm{mol}$ of Ins $P_{5}$ was recovered) before final submission to n.m.r. analysis (see below).

Approx. $20 \mu \mathrm{mol}$ of the Ins $P_{5}$ sample was dissolved in $3 \mathrm{ml}$ of ${ }^{2} \mathrm{H}_{2} \mathrm{O}$ and neutralized with $\mathrm{NaO}^{2} \mathrm{H}$ for use in all n.m.r. experiments. N.m.r. spectra were recorded on a Bruker wide-bore AM400 spectrometer operating at $400 \mathrm{MHz}$ for ${ }^{1} \mathrm{H}$ and 161.9 MHz for ${ }^{31} \mathrm{P} ; 400$ acquisitions were combined for each ${ }^{31} \mathrm{P}$ spectrum. Two-dimensional proton spectra were recorded with a phase-sensitive double quantum filter COSY programme using 512 segments each of 16 scans. The frequencies for decoupling specific ${ }^{31} \mathrm{P}$ resonances were measured from a proton spectrum acquired through the decoupler channel of the ${ }^{31} \mathrm{P}$ probe immediately before decoupling experiments. Clearly this could not be water-suppressed, and one of the proton resonances was hidden within this region. This proton was decoupled by progressively altering the decoupling frequency until there was a change in the ${ }^{31} \mathrm{P}$ spectrum.

\section{Assay of Ins $P_{5}$ kinase}

Assays were of $200-300 \mu$ l total volume and contained $0.1 \mathrm{M}$ $\mathrm{KCl}, 10 \mathrm{~mm}$-phosphocreatine, $1 \mathrm{~mm}$-dithiothreitol (or $15 \mathrm{~mm}-2$ mercaptoethanol), 5 units of creatine kinase (Sigma) $/ \mathrm{ml}, 5 \mathrm{mM}$ -

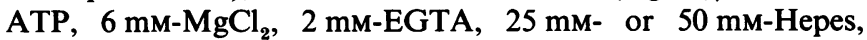
$0.3 \mathrm{~mm}^{-\mathrm{CaCl}_{2}}\left(\mathrm{pH} 7.0 ; 25^{\circ} \mathrm{C}\right.$ for Dictyostelium-derived and mung-bean-derived kinases, $37^{\circ} \mathrm{C}$ for rat-brain-derived kinases). The solution contains approx. $1 \mathrm{mM}$ free $\mathrm{Mg}^{2+}$ and $0.1 \mu \mathrm{M}$ free $\mathrm{Ca}^{2+}$. The Ins $P_{5}$ substrates used in the assays are defined in the Results section. Assays were quenched with $4.5 \% \mathrm{HClO}_{4}$ and 'spiked' with phytate hydrolysate (10 $\mu$ l of a solution containing $1.2 \mathrm{mg}$ of total phosphorus $/ \mathrm{ml}$ ) and $500-1000$ d.p.m. of $\left[{ }^{32} \mathrm{P}\right] \mathrm{Ins} P_{6}$. The acid-precipitated protein was pelleted by centrifugation, and the supernatants were removed and mixed with $2 \mathrm{M}-\mathrm{KOH} / 0.1 \mathrm{M}-\mathrm{Mes} / 25 \mathrm{~mm}$-EDTA $(200 \mu \mathrm{l})$. The final $\mathrm{pH}$ of the samples was $6.3-6.8$. The $\mathrm{KClO}_{4}$ was sedimented by 
centrifugation and the supernatants were applied either to an anion-exchange h.p.l.c. column or to batch-eluted resin columns (see above).

Removal of scintillation fluid and/or h.p.l.c. eluates from inositol phosphate preparations

Inositol phosphates that had been eluted from h.p.l.c. columns in phosphate buffers were desalted as described by Stephens $e t$ al. $(1988 b)$. In some situations, inositol phosphates were extracted from scintillation fluid (as described in Stephens \& Downes, 1990).

\section{Periodate oxidation, reduction and dephosphorylation of inositol} phosphates

H.p.l.c.-purified desalted preparations of inositol phosphates were periodate-oxidized, reduced and dephosphorylated precisely as described by Stephens (1990) and Stephens et al. (1988a). Unknown Ins $P_{4}$ s were oxidized with 0.1 M-periodic acid $(\mathrm{pH} 2.0$ with $\mathrm{NaOH})$ : under these conditions $\mathrm{D}$-Ins $(1,2,3,4) P_{4}$ and $\mathrm{L}$ Ins $(1,2,3,4) P_{4}$ give $\mathrm{L}$-altritol and $\mathrm{D}$-altritol respectively, and D-Ins $(1,2,5,6) P_{4}$ and L-Ins $(1,2,5,6) P_{4}$ give D-glucitol and L-glucitol respectively. All periodate oxidations were for $36 \mathrm{~h}$ in the dark at 20-25 ${ }^{\circ} \mathrm{C}$. Ins $P_{3}$ s were oxidized with $0.1 \mathrm{M}$-sodium periodate. To prepare periodate-sensitive Ins $P_{3} \mathrm{~s}$ and Ins $P_{4} \mathrm{~s}$ from cell-derived D- and/or L- $\left[{ }^{3} \mathrm{H}\right] \operatorname{Ins}(1,2,4,5,6) P_{5}$, the D- and/or L$\left[{ }^{3} \mathrm{H}\right] \operatorname{Ins}(1,2,4,5,6) P_{5}$ was partially dephosphorylated with Aspergillus phytase. Conditions were exactly as described above for Ins $P_{6}$, except that the phosphatase was used at $0.0016 \mathrm{unit} / \mathrm{ml}$.

\section{Oxidation of arabitol and glucitol by L-iditol dehydrogenase}

L-Arabitol (but not D) and D-glucitol (but not L) are oxidized by L-iditol dehydrogenase (see Fig. 2 and Stephens, 1990). Samples of $\left[{ }^{3} \mathrm{H}\right]$ arabitol of unknown configuration were incubated with $\mathrm{L}$-iditol dehydrogenase $(9.5 \mathrm{units} / \mathrm{ml})$ and $\mathrm{D}-\left[{ }^{14} \mathrm{C}\right]$ arabitol \{prepared from $\mathrm{D}-\left[{ }^{14} \mathrm{C}\right]$ arabinose (ICN Radiochemicals) as described by Stephens et al. (1988a)\} exactly as described previously (Stephens et al., 1989).

L- and D-arabitol were prepared by reduction of L- and D-arabinose respectively as described previously (Stephens et al., 1988a). L- $\left[{ }^{3} \mathrm{H}\right]$ Arabitol was prepared from L-arabinose by reduction with $\mathrm{NaB}^{3} \mathrm{H}_{4} ; 2 \mu \mathrm{g}$ of L-arabinose $(0.133 \mu \mathrm{mol})$ was mixed with $\mathrm{NaB}^{3} \mathrm{H}_{4}(1.33 \mu \mathrm{mol}, 0.6 \mathrm{mCi}$ in $7.5 \mu \mathrm{l}$ total volume). After $8 \mathrm{~h}$ the sample was mixed with $1 \mathrm{ml}$ of Bio-Rad AG50 $\left(\mathrm{H}^{+}\right.$ form) and processed as described previously (Stephens et al., $1988 a) ; 6 \mu \mathrm{Ci}$ of $\mathrm{L}-\left[{ }^{3} \mathrm{H}\right]$ arabitol was finally recovered.

Samples of $\left[{ }^{3} \mathrm{H}\right]$ glucitols were incubated with L-iditol dehydrogenase (2.5 units/ml) and $\mathrm{D}-\left[{ }^{14} \mathrm{C}\right]$ glucitol (Amersham) as described previously (Stephens et al., 1989). Polyols were separated on cation-exchange columns in the $\mathrm{Pb}^{2+}$ form (as described previously; Stephens et al., 1989).

\section{RESULTS}

\section{Definition and resolution of $\operatorname{Ins} \boldsymbol{P}_{5}$ standards}

To enable the Ins $P_{5} s$ in different tissues to be identified, a convenient chromatographic protocol and an appropriate set of 'standards' were required. There are six Ins $P_{5}$ isomers, which theoretically divide into four chromatographically distinct groups: Ins $(1,3,4,5,6) P_{5}$, Ins $(1,2,3,4,6) P_{5}$ (both of which contain a plane of symmetry) and D- and L-Ins $(1,2,3,4,5) P_{5}$ and Dand $L-I n s(1,2,4,5,6) P_{5}$ (see paragraph on nomenclature in the Introduction).

Ins $(1,3,4,5,6) P_{5}$ is the Ins $P_{5}$ found at a high concentration in avian erythrocytes (Johnson \& Tate, 1969) and can be readily prepared labelled with either ${ }^{32} \mathrm{P}$ or ${ }^{3} \mathrm{H}$ for use as a standard (Stephens et al., 1988a,b).
D- and/or L-Ins $(1,2,4,5,6) P_{5}$ was established to be the major Ins $P_{5}$ in germinating mung beans (in terms of both phosphate content and, in $\left[{ }^{32} \mathrm{P}\right] \mathrm{P}_{\mathrm{i}}-$ or $\left[{ }^{3} \mathrm{H}\right]-$ Ins-prelabelled cells, ${ }^{32} \mathrm{P}$ or ${ }^{3} \mathrm{H}$ content). An acid extract from $25 \mathrm{~g}$ (dry wt.) of mung beans was prepared, mixed with a portion of ${ }^{32} \mathrm{P}$-labelled inositol phosphates extracted from a $\left[{ }^{32} \mathrm{P}\right] \mathrm{P}_{1}$-labelled germinating mung bean, and the major ${ }^{32} \mathrm{P}$-labelled $\operatorname{Ins} P_{5}$ was purified to homogeneity by anion-exchange chromatography (see Fig. 3); $20.6 \mu \mathrm{mol}$ of an Ins $P_{5}$ was recovered and submitted to n.m.r. analysis (see the Materials and methods section, and Fig. 4 and its legend). The results established that the major $\operatorname{Ins} P_{5}$ in germinating mung beans is $\mathrm{D}$ - and/or L-Ins $(1,2,4,5,6) P_{5}$. This source of ${ }^{3} \mathrm{H}$ - or ${ }^{32} \mathrm{P}$-labelled $\mathrm{D}$ - and/or $\mathrm{L}$-Ins $(1,2,4,5,6) P_{5}$ was then used, by co-chromatography (see below), to confirm that: (a) the principal Ins $P_{5}$ formed by a commercially available fungal phytase (from Aspergillus; see the Materials and methods section) was also D- and/or L-Ins $(1,2,4,5,6) P_{5}$ (as described previously; Irving \& Cosgrove, 1972) and $(b)$ the predominant Ins $P_{5}$ generated during alkaline hydrolysis of $\operatorname{Ins} P_{6}$ was $\mathrm{D} / \mathrm{L}-$ Ins $(1,2,4,5,6) P_{5}$ (Cosgrove, 1980).

D- and/or L-Ins $(1,2,3,4,5) P_{5}$ [predominantly L-; see Tomlinson \& Ballou (1961) and later Lim \& Tate (1973)] was prepared from Ins $P_{6}$ with a commercially available wheat-bran phytase (see the Materials and methods section). Once the wheat-bran phytase-derived Ins $P_{5}$ was available, it enabled us to establish that the only other detectable Ins $P_{5}$ found in germinating mung beans was D- and/or L-Ins $(1,2,3,4,5) P_{5}$ (results not shown).

With three of the four possible chromatographic classes of Ins $P_{5}$ (prepared as described above) to serve as markers, Ins $(1,2,3,4,6) P_{5}$ was then identified in (and subsequently isolated from) alkaline hydrolysates of Ins $P_{6}$ by a process of elimination.

The process of characterizing various sources of $\operatorname{Ins} P_{5} \mathrm{~s}$ not only represented a mechanism to verify the identity of those Ins $P_{5}$

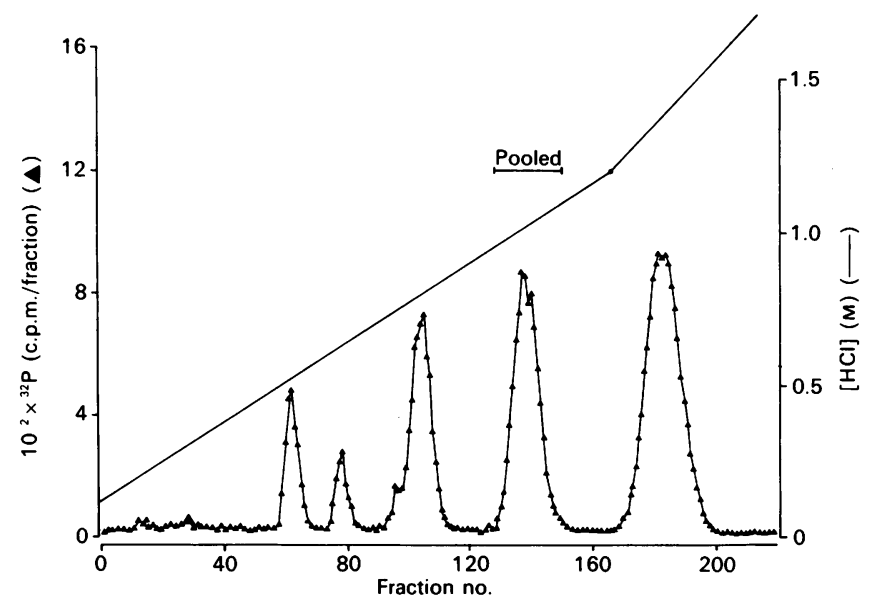

Fig. 3. Purification of mung-bean Ins $P_{5} s$ by anion-exchange chromatography

An acid extract from $25 \mathrm{~g} /$ dry wt. of germinating mung beans was prepared as described in the Materials and methods section and mixed with $\left[{ }^{32} \mathrm{P}\right] \operatorname{Ins} P_{4} \mathrm{~s}$ (two), $\left[{ }^{32} \mathrm{P}\right] \operatorname{Ins} P_{5} \mathrm{~s}$ (two) and $\left[{ }^{32} \mathrm{P}\right] \operatorname{Ins} P_{6}$ (h.p.l.c. purified from a [ $\left.{ }^{32} \mathrm{P}\right] \mathrm{P}_{\mathrm{i}}$-labelled mung-bean preparation) and loaded on to a $62 \mathrm{~cm} \times 2 \mathrm{~cm}$ column of Bio-Rad AG $1 \times 8200-400$ resin (chloride form). The column was eluted with $\mathrm{HCl}$ at $2.5 \mathrm{ml} / \mathrm{min}$ as shown in the Figure and as described in the Materials and methods section (24 ml fractions were collected). The second eluted $\left.{ }^{32} \mathrm{P}\right] \mathrm{Ins} P_{5}$ (marked in the Figure) was collected and desalted; $20.6 \mu \mathrm{mol}$ of Ins $P_{5}$ was finally recovered and submitted for n.m.r. analysis (see Fig. 4). 

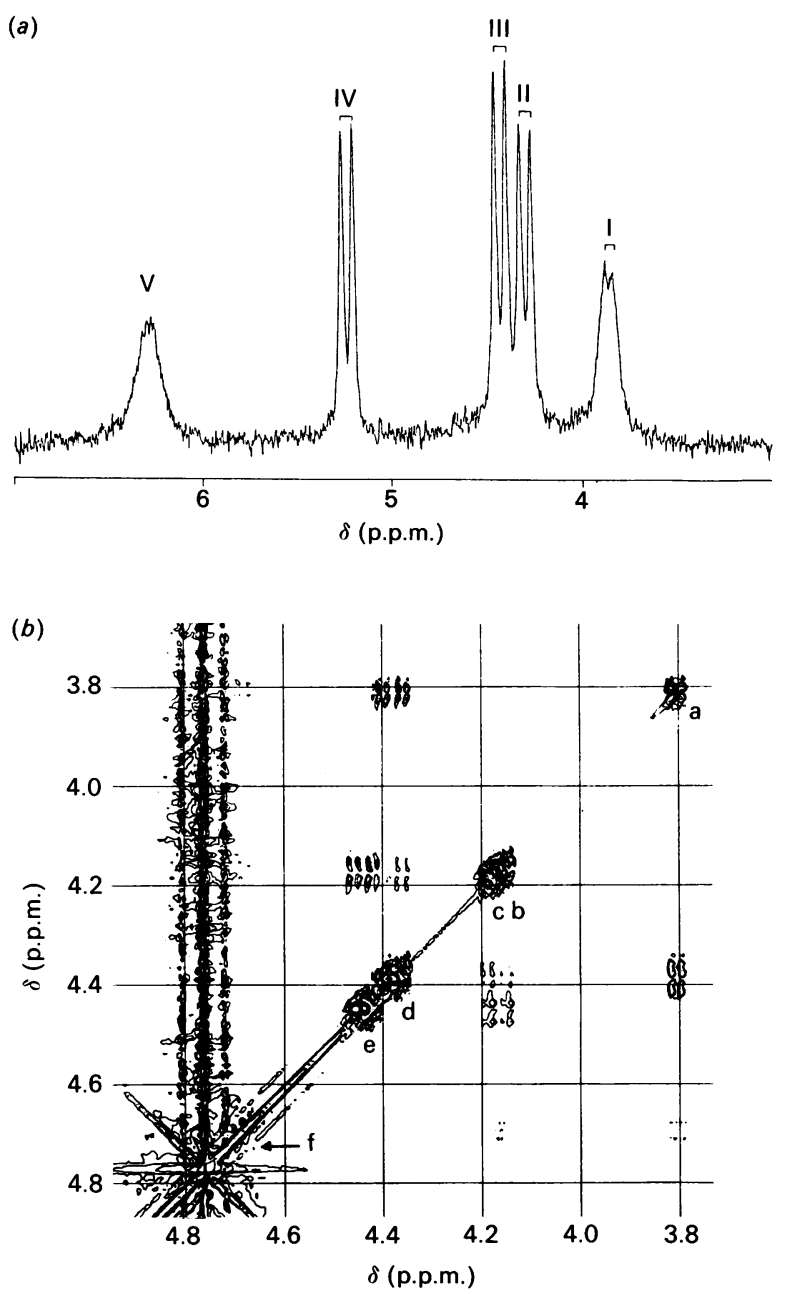

Fig. 4. N.m.r. analysis of mung-bean-derived $\operatorname{Ins} P_{5}$

(a) ${ }^{31} \mathrm{P}$ spectrum of the mung-bean Ins $P_{5}$ (operation at $161.9 \mathrm{MHz}$ ); (b) ${ }^{1} \mathrm{H}$ COSY spectrum of the mung-bean Ins $P_{5}$ (operation at $161.9 \mathrm{MHz}$ ). The ${ }^{31} \mathrm{P}$ spectrum of the unknown compound showed five peaks labelled $\mathrm{I}-\mathrm{V}$ in $(a) .{ }^{31} \mathrm{P}$ signals originating from the phosphates attached to $\mathrm{C}-1$ and $\mathrm{C}-3$, or $\mathrm{C}-4$ and $\mathrm{C}-6$, would be expected to be magnetically very similar (Zuiderweg et al., 1979), so that the presence of only one closely spaced pair of resonances suggested that the non-phosphorylated carbon is one of these four. A double quantum filtered COSY proton spectrum $(b)$ indicated one proton resonance shifted downfield enough to be hidden within the residual water resonance. This can only be the anomeric proton attached to a phosphorylated C-2 (Radenberg et al., 1989) and is labelled ' $\mathrm{f}$ ' in (b). Comparison with spectra from Radenberg $e t$ al. (1989), Mayr \& Dietrich (1987) and Cerdan et al. (1986), as well as examination of connectivity from the COSY spectrum allocates resonances ' $e$ ' and ' $d$ ' to protons from C-4 and C-6 (order not determined), resonances ' $c$ ' and ' $b$ ' to protons from C-5 and C-1 (or $\mathrm{C}$-3) (order again not determined) and resonance ' $\mathrm{a}$ ' to the proton from $\mathrm{C}-1$ or $\mathrm{C}-3$. The response of the ${ }^{31} \mathrm{P}$ spectrum to narrow-band proton-decoupling linked proton resonances ' $b$ ', ' $c$ ', ' $d$ ' and ' $e$ ' to phosphorus resonances IV, I, II and III respectively, i.e. C-4, C-5 and C-6, are phosphorylated and one of C-1 or C-3. Progressive decoupling within narrow frequency ranges in the region of the proton resonance ' $\mathrm{f}$ ' (see the Materials and methods section) confirmed that this was linked to phosphorus V, i.e. C-2 is phosphorylated. Hence the unknown inositol compound is D- and/or L-Ins $(1,2,4,5,6) P_{5}$.

isomers, but also enabled both ${ }^{3} \mathrm{H}$ - and ${ }^{32} \mathrm{P}$-labelled forms of all the chromatographically distinct classes of $\operatorname{Ins} P_{5}$ to be prepared for use as standards.

The chromatographic conditions that evolved in parallel with

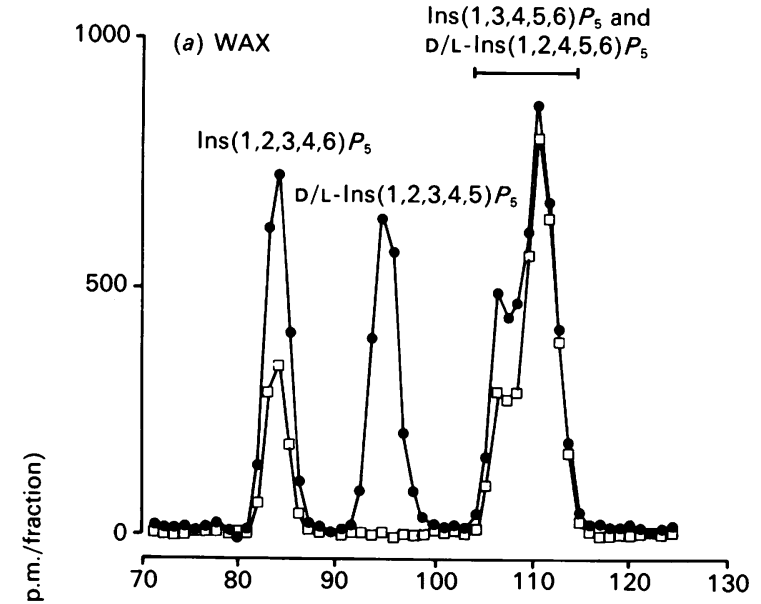

(b) SAX

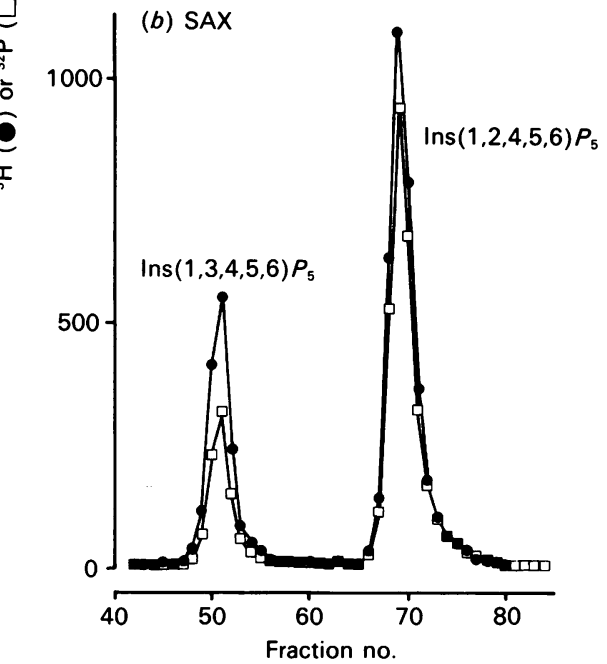

Fig. 5. Resolution by h.p.l.c. of $\left.\right|^{32} \mathbf{P} \mid I n s P_{5} s$ in an acid extract from $\left[{ }^{32} \mathbf{P} \mid P_{i}-\right.$ prelabelled Dictyostelium amoebae

NC4 amoebae were incubated with $\left[{ }^{32} \mathrm{P}\right] \mathrm{P}_{\mathrm{i}}$ for $4 \mathrm{~h}$ and an acid extract was prepared and mixed with various $\left[{ }^{3} \mathrm{H}\right] \mathrm{Ins} P_{5} \mathrm{~s}$ $\left\{\left[{ }^{3} \mathrm{H}\right] \operatorname{Ins}(1,3,4,5,6) P_{5}, \quad \mathrm{D} / \mathrm{L}-\left[{ }^{3} \mathrm{H}\right] \operatorname{Ins}(1,2,4,5,6) P_{5}, \quad\left[{ }^{3} \mathrm{H}\right] \operatorname{Ins}(1,2,3,4,6) P_{5}\right.$ and $\mathrm{D} / \mathrm{L}-\left[{ }^{3} \mathrm{H}\right] \operatorname{Ins}(1,2,3,4,5) P_{5} ;$ see the Materials and methods section $\}$. The sample was then chromatographed on a Partisphere WAX h.p.l.c. column. The region in which the $\left[{ }^{3} \mathrm{H}\right] \operatorname{Ins} P_{5} \mathrm{~s}$ were eluted is shown in $(a)$. They were eluted in the order $\left[{ }^{3} \mathrm{H}\right] \operatorname{Ins}(1,2,3,4,6) P_{5}$, D/L- $\left[{ }^{3} \mathrm{H}\right] \operatorname{Ins}(1,2,3,4,5) P_{5}, \quad\left[{ }^{3} \mathrm{H}\right] \operatorname{Ins}(1,3,4,5,6) P_{5}$ and $\mathrm{D} / \mathrm{L}-\left[{ }^{3} \mathrm{H}\right]$ Ins$(1,2,4,5,6) P_{5}$ (increasing retention time). The peak marked with a horizontal bar was pooled, desalted and chromatographed on a Partisphere SAX h.p.l.c. column $(40 \%$ of each fraction was removed and counted for ${ }^{3} \mathrm{H}$ and ${ }^{32} \mathrm{P}$ radioactivity). The region in which the $\left[{ }^{3} \mathrm{H}\right] \operatorname{Ins} P_{5}$ s were eluted is shown in $(b)$. The $\left[{ }^{3} \mathrm{H}\right]-$ and $\left[{ }^{32} \mathrm{P}\right]-$ Ins $P_{5} \mathrm{~s}$ were resolved into two peaks, the first-eluted being $\left[{ }^{3} \mathrm{H}\right] \operatorname{Ins}(1,3,4,5,6) P_{5}$ and the second $\mathrm{D} / \mathrm{L}-\left[{ }^{3} \mathrm{H}\right] \operatorname{Ins}(1,2,4,5,6) P_{5}$.

the process of preparing and testing the Ins $P_{5}$ preparations described above are based on those standardly used during h.p.l.c. analysis of $\operatorname{Ins} P_{3}$ s and $\operatorname{Ins} P_{4}$ s (see the Materials and methods section). On a weak anion-exchange h.p.l.c. column the order of elution was $\operatorname{Ins}(1,2,3,4,6) P_{5}, \operatorname{Ins}(1,2,3,4,5) P_{5}$, $\operatorname{Ins}(1,3,4,5,6) P_{5}$ and $\operatorname{Ins}(1,2,4,5,6) P_{5}$ (in order of increasing retention time, the last two isomers running relatively close together); on a strong anion-exchange h.p.l.c. column, the order was $\operatorname{Ins}(1,3,4,5,6) P_{5}, \quad \operatorname{Ins}(1,2,3,4,5) P_{5}, \quad \operatorname{Ins}(1,2,3,4,6) P_{5}$ and Ins $(1,2,4,5,6) P_{5}$ (the last two isomers are relatively close together). This compares with $60 \mathrm{~cm}$-long $\mathrm{AG}-1$ ( $\mathrm{Cl}^{-}$form) anion-exchange columns eluted with $\mathrm{HCl}$, in which the elution order is $\operatorname{Ins}(1,2,3,4,6) P_{5}$, Ins $(1,2,3,4,5) P_{5}, \operatorname{Ins}(1,2,4,5,6) P_{5}$ and 

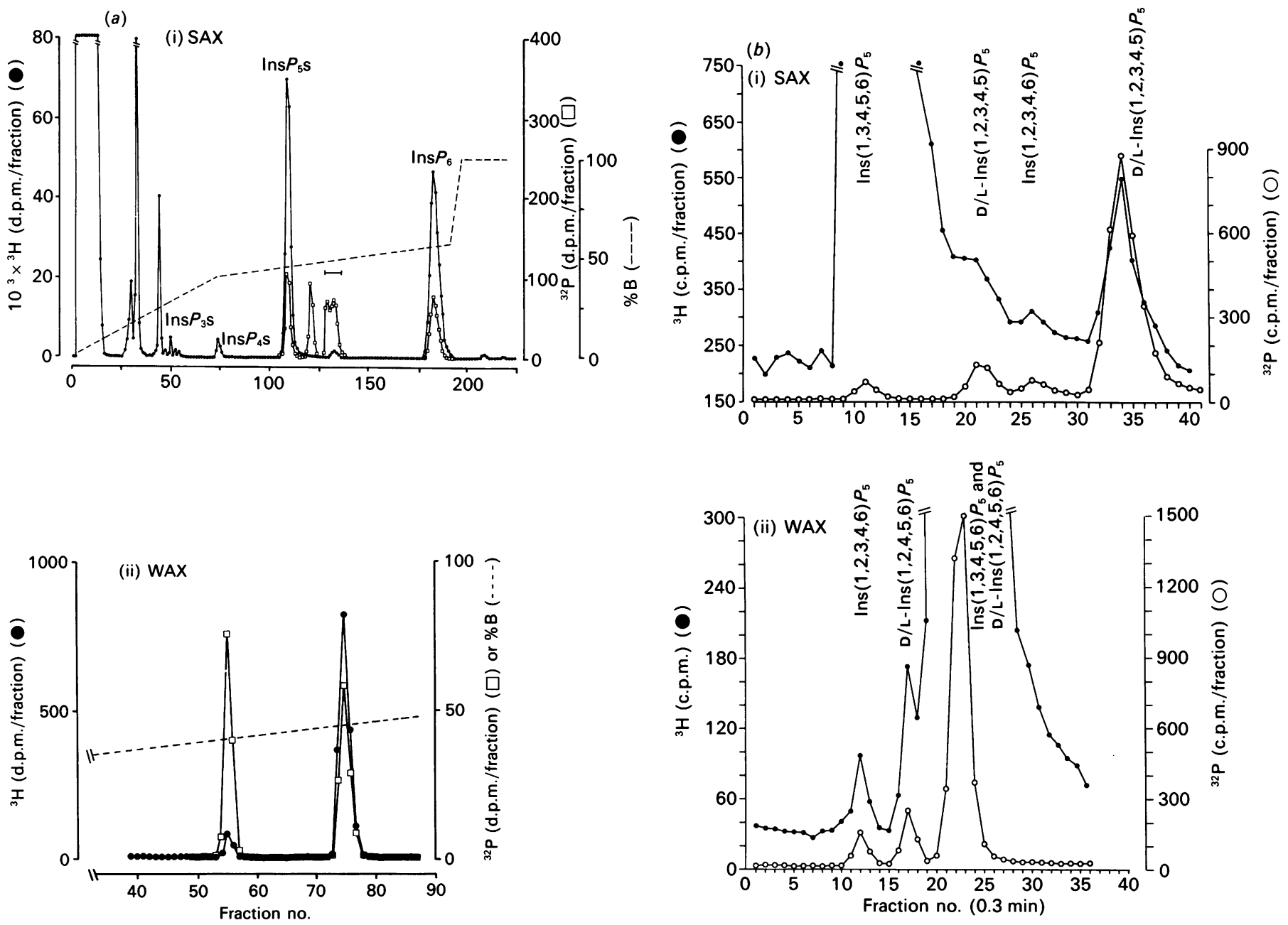

Fig. 6. Resolution of $\left[{ }^{3} \mathrm{H}\right]$ Ins $P_{5} \mathrm{~s}$ in $\left[{ }^{3} \mathrm{H}\right]$ Ins-prelabelled $\mathrm{HL60}$ cells and NG-115-401L-C3 cells

(a) HL60 cells were prelabelled with $\left[{ }^{3} \mathrm{H}\right]$ Ins and an acid extract was prepared and mixed with $\left[{ }^{32} \mathrm{P}\right] \operatorname{Ins} P_{6},\left[{ }^{32} \mathrm{P}\right] \operatorname{Ins}(1,3,4,5,6) P_{5},\left[{ }^{32} \mathrm{P}\right] \operatorname{Ins}(1,2,3,4,6) P_{5}$, $\mathrm{D} / \mathrm{L}-\left[{ }^{32} \mathrm{P}\right] \operatorname{Ins}(1,2,3,4,5) P_{5}$ and $\mathrm{D} / \mathrm{L}-\left[{ }^{32} \mathrm{P}\right] \operatorname{Ins}(1,2,4,5,6) P_{5}$ (see the Materials and methods section). The sample was filtered, applied to a Partisphere SAX h.p.l.c. column, eluted and counted $\left(50 \%\right.$ of each fraction) for ${ }^{3} \mathrm{H}$ and ${ }^{32} \mathrm{P}$ radioactivity $(a \mathrm{i})$. The standards were eluted in the order $\left[{ }^{32} \mathrm{P}\right] \operatorname{Ins}(1,3,4,5,6) P_{5}, \mathrm{D} / \mathrm{L}-\left[{ }^{32} \mathrm{P}\right] \operatorname{Ins}(1,2,3,4,5) P_{5},\left[{ }^{32} \mathrm{PIns}(1,2,3,4,6) P_{5}\right.$ and $\mathrm{D} / \mathrm{L}-\left[{ }^{32} \mathrm{P}\right] \operatorname{Ins}(1,2,4,5,6) P_{5}$ (the last two together, in order of increasing retention time). The fractions marked by a horizontal bar were pooled, desalted and re-applied to a Partisphere WAX h.p.l.c. column. The region in which the Ins $P_{5}$ s were eluted is shown (aii). The standards were eluted in the order $\left[{ }^{32} \mathrm{P}\right] \operatorname{Ins}(1,2,3,4,6) P_{5}$ and $\mathrm{D} / \mathrm{L}-\left[{ }^{32} \mathrm{P}\right] \operatorname{Ins}(1,2,4,5,6) P_{5}$ (in order of increasing retention time). $\left[{ }^{3} \mathrm{H}\right]$ Ins-prelabelled $\mathrm{HL} 60$ cells contained $\left[{ }^{3} \mathrm{H}\right] \operatorname{Ins}(1,3,4,5,6) P_{5}$ (in substantial excess over the other isomers), $\left[{ }^{3} \mathrm{H}\right] \mathrm{Ins}(1,2,3,4,6) P_{5}$ and $\mathrm{D}$ - and/or $\mathrm{L}-\left[{ }^{3} \mathrm{H}\right] \mathrm{Ins}(1,2,4,5,6) P_{5} .(b)$ NG-1 15-401L-C3 cells were prelabelled with $\left[{ }^{3} \mathrm{H}\right]$ Ins and an acid extract was prepared and mixed with $\left[{ }^{32} \mathrm{P}\right] \operatorname{Ins}(1,3,4,5,6) P_{5},\left[{ }^{32} \mathrm{P}\right] \operatorname{Ins}(1,2,3,4,6) P_{5}, \mathrm{D} / \mathrm{L}-\left[{ }^{32} \mathrm{P}\right] \operatorname{Ins}(1,2,3,4,5) P_{5}$ and $\mathrm{D} / \mathrm{L}-\left[{ }^{32} \mathrm{P}\right] \operatorname{Ins}(1,2,4,5,6) P_{5}$ (see the Materials and methods section). The sample was filtered, divided into two, and one half was chromatographed on a Partisphere SAX h.p.l.c. column (bi) and the other on a Partisphere WAX h.p.l.c. column (bii). The regions in which the Ins $P_{5}$ s were eluted are shown. Approx. 91000 c.p.m. and 65000 c.p.m. of $\left[{ }^{3} \mathrm{H}\right] \operatorname{Ins}(1,3,4,5,6) P_{5}$ was recovered from the SAX and WAX columns respectively. The order of elution of the $\left[{ }^{32} \mathrm{P}\right]$ Ins $P_{5}$ standards is described in the legends to Figs. 5 and $6 a$ (above). $\left[{ }^{3} \mathrm{H}\right]$ Ins-prelabelled NG-115-401 L-C 3 cells contained $\left[{ }^{3} \mathrm{H}\right]$ Ins $(1,3,4,5,6) P_{5}$ (in substantial excess over the other isomers), $\left[{ }^{3} \mathrm{H}\right] \operatorname{Ins}(1,2,3,4,6) P_{5}, \mathrm{D}$ - and/or L-Ins $(1,2,3,4,5) P_{6}$ and $\mathrm{D}$ - and/or L-Ins $(1,2,4,5,6) P_{5}$. This experiment has been repeated once with very similar results.

Ins $(1,3,4,5,6) P_{5} \quad$ (Cosgrove, 1969; P. T. Hawkins \& L. R. Stephens, results not shown). In all cases the order of elution was established by co-injection of different combinations of various contrastingly labelled $\left({ }^{32} \mathrm{P}\right.$ or $\left.{ }^{3} \mathrm{H}\right) \operatorname{Ins} P_{5}$ s.

\section{Ins $\boldsymbol{P}_{5} \mathbf{s}$ in germinating mung beans}

The presence of D- and/or L-Ins(1,2,4,5,6) $P_{5}$ and D- and/or L-Ins $(1,2,3,4,5) P_{5}$ in germinating mung beans was established as part of the process of preparing 'standard' Ins $P_{5} s$ and characterizing methods capable of separating them as described above. In $\left[{ }^{3} \mathrm{H}\right]$ Ins- or $\left[{ }^{32} \mathrm{P}\right] \mathrm{P}_{1}$-labelled preparations less than $4 \%$ of the total radiolabelled $\operatorname{Ins} P_{5}$ fractions were in $\operatorname{Ins}(1,3,4,5,6) P_{5}$ and $\operatorname{Ins}(1,2,3,4,6) P_{5}$. During the germination of many seeds there is a net breakdown of the $\operatorname{Ins} P_{6}$ deposited in the storage tissues
(Williams, 1970). However, because both $\left[{ }^{3} \mathrm{H}\right]$ Ins and $\left[{ }^{32} \mathrm{P}\right] \mathrm{P}_{1}$ are rapidly incorporated into Ins $P_{6}$ during the germination of the mung-bean seed (see above; Stephens, 1990; Biswas \& Biswas, 1965), it can be reasoned that significant synthesis of Ins $P_{6}$ is also occurring, presumably in a different tissue. Clearly the presence of particular Ins $P_{5}$ species during germination could be associated with the process of either synthesis or degradation of $\operatorname{Ins} P_{6}$.

\section{Ins $\boldsymbol{P}_{5}$ in Dictyostelium}

Acid extracts of $\left[{ }^{32} \mathrm{P}\right] \mathrm{P}_{1}$-prelabelled Dictyostelium discoidium amoebae were prepared, spiked with $\left[{ }^{3} \mathrm{H}\right] \mathrm{Ins} P_{5}$ standards, and resolved sequentially on weak and strong anion-exchange h.p.l.c. columns (see Fig. 5 and the Materials and methods section). ${ }^{32} \mathrm{P}$ labelled compounds co-migrated on a weak anion-exchange 
Table 1. Dephosphorylation of Dictyostelium-derived $\left.\mathrm{D}-\left.\right|^{3} \mathrm{H}\right] \mathrm{Ins}(1,2,4,5,6) P_{5}$ and identification of the products

The D- $\left[{ }^{3} \mathrm{H}\right] \mathrm{Ins}(1,2,4,5,6) P_{5}$ preparations were purified from $\left[{ }^{3} \mathrm{H}\right]$ Ins-prelabelled amoebae and then dephosphorylated with an Aspergillus phytase preparation (see the Materials and methods section). The $\left[{ }^{3} \mathrm{H}\right] \mathrm{Ins} P_{4}$ and $\left[{ }^{3} \mathrm{H}\right] \mathrm{Ins} P_{3}$ products were purified by h.p.l.c., then periodate-oxidized, reduced and dephosphorylated (see the Materials and methods section). The $\left[{ }^{3} \mathrm{H}\right]$ polyols recovered were identified and incubated with L-iditol dehydrogenase (see the Materials and methods section).

\begin{tabular}{|c|c|c|c|c|}
\hline $\begin{array}{l}\text { D- }\left[{ }^{3} \mathrm{H}\right] \operatorname{Ins}(1,2,4,5,6) P_{5} \\
\text { preparation } \\
\text { (initial d.p.m.) }\end{array}$ & $\begin{array}{c}\text { Percentage of total } \\
{\left[{ }^{3} \mathrm{H}\right] \text { Ins } P_{5}} \\
\text { dephosphorylated }\end{array}$ & $\begin{array}{c}\text { Percentage of total }{ }^{3} \mathrm{H} \\
\text { in }\left[{ }^{3} \mathrm{H}\right] \text { Ins } P_{4} \text { or } \\
{\left[{ }^{3} \mathrm{H}\right] \mathrm{Ins} P_{3} \text { to be }} \\
\text { analysed }\end{array}$ & $\begin{array}{c}\text { Polyols } \\
\text { recovered } \\
(\% \text { recovery })\end{array}$ & $\begin{array}{c}\text { Oxidation with } \\
\text { L-iditol dehydrogenase } \\
\text { (overall } \% \text { recovery) }\end{array}$ \\
\hline A (28000 d.p.m.) & $50 \%$ & $8 \%\left[{ }^{3} \mathrm{H}\right] \operatorname{Ins} P_{3}(\mathrm{~s})$ & $\begin{array}{l}{\left[{ }^{3} \mathrm{H}\right] \text { Arabitol }} \\
(70 \%)\end{array}$ & $\begin{array}{l}\text { D- }\left[{ }^{3} \mathrm{H}\right] \text { Arabitol } \\
(80 \%)\end{array}$ \\
\hline B (90000 d.p.m.) & $28 \%$ & $10 \%\left[{ }^{3} \mathrm{H}\right] \operatorname{Ins} P_{4}(\mathrm{~s})$ & $\begin{array}{l}70 \%\left[{ }^{3} \mathrm{H}\right] \text { glucitol } \\
30 \%\left[{ }^{3} \mathrm{H}\right] \text { Ins } \\
(85 \%)\end{array}$ & $\begin{array}{l}89 \% \text { D-glucitol } \\
11 \% \text { L-glucitol } \\
(90 \%)\end{array}$ \\
\hline
\end{tabular}

column with $\left[{ }^{3} \mathrm{H}\right] \operatorname{Ins}(1,2,3,4,6) P_{5}$ and the peak containing $\mathrm{D} / \mathrm{L}$ $\left[{ }^{3} \mathrm{H}\right] \operatorname{Ins}(1,2,4,5,6) P_{5}$ and $\left[{ }^{3} \mathrm{H}\right] \operatorname{Ins}(1,3,4,5,6) P_{5}$. When the latter peak was desalted and re-applied to a strong anion-exchange h.p.l.c. column, both the ${ }^{3} \mathrm{H}$ and ${ }^{32} \mathrm{P}$ were resolved into two peaks. Furthermore, amoebae which were prelabelled with $\left[{ }^{3} \mathrm{H}\right] \mathrm{Ins}$ yielded acid extracts containing $\left[{ }^{3} \mathrm{H}\right]$ Ins-labelled peaks which comigrated with $\left[{ }^{32} \mathrm{P}\right] \operatorname{Ins}(1,2,4,5,6) P_{5}, \quad\left[{ }^{32} \mathrm{P}\right] \operatorname{Ins}(1,2,3,4,6) P_{5}$ and $\left[{ }^{32} \mathrm{P}\right] \operatorname{Ins}(1,3,4,5,6) P_{5}$ (results not shown). Together, these observations suggest that $\mathrm{NC} 4$ amoebae contain at least three $\operatorname{Ins} P_{5} \mathrm{~s}$ : $\operatorname{Ins}(1,2,3,4,6) P_{5}, \operatorname{Ins}(1,3,4,5,6) P_{5}$ and D- and/or L-Ins $(1,2,4,5,6) P_{5}$. Ins $P_{5} \mathrm{~s}$ and Ins $P_{6}$ were purified from $\left[{ }^{3} \mathrm{H}\right]$ Ins-prelabelled amoebae, and both their intracellular radiochemical concentrations (in d.p.m. $/ \mu \mathrm{l}$ ) and the specific radioactivity of their inositol moieties were determined (by dephosphorylating the inositol polyphosphates with alkaline phosphatase and assaying both the concentration and ${ }^{3} \mathrm{H}$ content of the liberated inositol; see Stephens \& Irvine, 1990), and hence their original intracellular chemical concentrations could be calculated. Ins $(1,3,4,5,6) P_{5}$, $\operatorname{Ins}(1,2,3,4,6) P_{5}$, D- and/or L-Ins $(1,2,4,5,6) P_{5}$ and $\operatorname{Ins} P_{6}$ were present at concentrations of $8 \mu \mathrm{M}, 16 \mu \mathrm{M}, 36 \mu \mathrm{M}$ and $600 \mu \mathrm{M}$ respectively (Stephens \& Irvine, 1990).

\section{Ins $P_{5} \mathbf{s}$ in mammalian cell lines}

$\left[{ }^{3} \mathrm{H}\right]$ Ins-prelabelled HL60 and NG115 401L-C3 cells yielded acid extracts containing relatively very large amounts of $\left[{ }^{3} \mathrm{H}\right] \operatorname{Ins}(1,3,4,5,6) P_{5}$ and smaller amounts of $\mathrm{D}-$ and/or $\mathrm{L}-\left[{ }^{3} \mathrm{H}\right] \operatorname{Ins}(1,2,4,5,6) P_{5}, \quad$ D- and/or $\quad \mathrm{L}-\left[{ }^{3} \mathrm{H}\right] \operatorname{Ins}(1,2,3,4,5) P_{5}$ and $\left[{ }^{3} \mathrm{H}\right] \operatorname{Ins}(1,2,3,4,6) P_{5}$ (see Fig. 6). It is unlikely that the radioactivity in the $\mathrm{D}$ - and/or $\mathrm{L}-\left[{ }^{3} \mathrm{H}\right] \mathrm{Ins}(1,2,4,5,6) P_{5}$ peak results from acidcatalysed phosphate migration of $\left[{ }^{3} \mathrm{H}\right] \operatorname{Ins}(1,3,4,5,6) P_{5}$, which would cause $\mathrm{D} / \mathrm{L}$-Ins $(1,2,4,5,6) P_{5}$ formation, as similar extraction protocols applied to avian erythrocytes have reproducibly given acid extracts containing no detectable $\mathrm{D} / \mathrm{L}-\mathrm{Ins}(1,2,4,5,6) P_{5}$ (results not shown). Identical relative distributions of $\left[{ }^{3} \mathrm{H}\right]$ Ins label between these $\left[{ }^{3} \mathrm{H}\right] \operatorname{Ins} P_{5}$ s and $\left[{ }^{3} \mathrm{H}\right] \mathrm{Ins} P_{6}$ were seen after 10 days labelling with $\left[{ }^{3} \mathrm{H}\right]$ Ins under these conditions; over $99 \%$ of the cells in the cultures had been 'synthesized' in the presence of $\left[{ }^{3} \mathrm{H}\right] \mathrm{Ins}$, hence it is very likely this distribution of ${ }^{3} \mathrm{H}$ radioactivity is a true reflection of the inositol phosphates' relative concentrations.

\section{Stereochemical assignment of $D-$ and/or $L-I n s(1,2,4,5,6) P_{5}$ found in Dictyostelium discoidium amoebae}

D- and/or L- $\left[{ }^{3} \mathrm{H}\right] \operatorname{Ins}(1,2,4,5,6) P_{5}$ was h.p.l.c.-purified (by both strong and weak anion-exchange h.p.l.c. columns) from $\left[{ }^{3} \mathrm{H}\right]$ Insprelabelled amoebae, then partially dephosphorylated with an Aspergillus-derived phytase preparation (see the Materials and methods section). Two independent preparations of $\mathrm{D}$ - and/or L$\left[{ }^{3} \mathrm{H}\right] \operatorname{Ins}(1,2,4,5,6) P_{5}$ were dephosphorylated to different extents (see Table 1) and the products were resolved by anion-exchange h.p.l.c. The $\left[{ }^{3} \mathrm{H}\right] \mathrm{Ins} P_{3}$ peak yielded $\left[{ }^{3} \mathrm{H}\right]$ arabitol and was therefore either D- or L- $\left[{ }^{3} \mathrm{H}\right] \mathrm{Ins}(1,2,6) P_{3}$; traces of $\left[{ }^{3} \mathrm{H}\right]$ glucitol were also obtained, but because of the ambiguity in the way $\left[{ }^{3} \mathrm{H}\right]$ glucitol can be derived from $\left[{ }^{3} \mathrm{H}\right] \mathrm{Ins} P_{3}$ s this was not further analysed. The $\left[{ }^{3} \mathrm{H}\right]$ Ins $P_{4}$ peak yielded $\left[{ }^{3} \mathrm{H}\right]$ glucitol, meaning some D- or $\mathrm{L}$ $\left[{ }^{3} \mathrm{H}\right]$ Ins $(1,2,5,6) P_{4}$ was present. Also formed (Table 1$)$ was $\left[{ }^{3} \mathrm{H}\right] \mathrm{Ins}$, which could be derived from D- or L- $\left[{ }^{3} \mathrm{H}\right] \operatorname{Ins}(1,2,4,5) P_{4}$, D- or L$\left[{ }^{3} \mathrm{H}\right] \operatorname{Ins}(1,2,4,6) P_{4}$ or $\left[{ }^{3} \mathrm{H}\right] \operatorname{Ins}(2,4,5,6) P_{4}$ [if it is accepted that only Ins $P_{4}$ derived from D- and/or L-Ins $(1,2,4,5,6) P_{5}$ could not possess phosphate groups at both the $\mathrm{D}$ - and $\mathrm{L}-3$ positions]. The alternative explanation for the presence of $\left[{ }^{3} \mathrm{H}\right]$ Ins amongst the periodate-oxidation, reduction and dephosphorylation products of the $\left[{ }^{3} \mathrm{H}\right] \operatorname{Ins} P_{4}(\mathrm{~s})$ is that the $\left[{ }^{3} \mathrm{H}\right] \operatorname{Ins} P_{4}$ that yielded $\left[{ }^{3} \mathrm{H}\right]$ glucitol was incompletely oxidized; this is unlikely to be true, as independent preparations of $\mathrm{D}-\left[{ }^{3} \mathrm{H}\right] \operatorname{Ins}(1,2,5,6) P_{4}$ that were oxidized in parallel only gave D- $\left[{ }^{3} \mathrm{H}\right]$ glucitol (see Stephens, 1990 ; L. R. Stephens, unpublished work). D- but not L-glucitol is oxidized to fructose by L-iditol dehydrogenase (Stephens et al., 1990; Stephens, 1990). L- but not D-arabitol is oxidized to ribulose and xylulose by L-iditol dehydrogenase (see Fig. 2, the Materials and methods section and Stephens, 1990). The substrate selectivity of yeast-derived L-iditol dehydrogenase was therefore exploited to determine the chirality of the $\left[{ }^{3} \mathrm{H}\right]$ arabitol and $\left[{ }^{3} \mathrm{H}\right]$ glucitol which had originated from the dephosphorylation products of $\mathrm{D}$ - and/or $\mathrm{L}-\left[{ }^{3} \mathrm{H}\right] \operatorname{Ins}(1,2,4,5,6) P_{5}$. The assays were designed to operate according to the principles previously defined (Stephens et al., 1988a, 1989; Stephens, 1990; see the legend to Fig. 2). The $\left[{ }^{3} \mathrm{H}\right]$ arabitol in question was completely unoxidized ( $88 \%$ of the starting material was recovered) in an assay in which $50 \%$ of the starting internal L-arabitol had been oxidized. Some $80 \%$ of the $\left[{ }^{3} \mathrm{H}\right]$ glucitol was oxidized in an assay in which $90 \%$ of the internal $\mathrm{D}-\left[{ }^{14} \mathrm{C}\right]$ glucitol had been oxidized. These results are consistent with the $\left[{ }^{3} \mathrm{H}\right] \mathrm{Ins} P_{3}$ and $\left[{ }^{3} \mathrm{H}\right] \mathrm{Ins} P_{4}$ derived from the $\mathrm{D}$ - and/or $\mathrm{L}$-Ins $(1,2,4,5,6) P_{5}$ possessing the structures D- $\left[{ }^{3} \mathrm{H}\right] \operatorname{Ins}(1,2,6) P_{3}$ and $\mathrm{D}-\left[{ }^{3} \mathrm{H}\right] \operatorname{Ins}(1,2,5,6) P_{4}$ and hence the original ${ }^{3} \mathrm{H}$-Ins $P_{5}$ must have been $\mathrm{D}-\left[{ }^{3} \mathrm{H}\right] \operatorname{Ins}(1,2,4,5,6) P_{5}$. The small quantity of $\mathrm{L}-\left[{ }^{3} \mathrm{H}\right]$ glucitol detected in the latter assay (approx. $11 \%$ of the total) suggests that in that preparation $11 \%$ of the $\left[{ }^{3} \mathrm{H}\right] \operatorname{Ins} P_{4}$ was L- $\left[{ }^{3} \mathrm{H}\right] \operatorname{Ins}(1,2,5,6) P_{4}$, and hence some of the original $\left[{ }^{3} \mathrm{H}\right] \operatorname{Ins} P_{5}$ was possibly $\mathrm{L}-\left[{ }^{3} \mathrm{H}\right] \operatorname{Ins}(1,2,4,5,6) P_{5}$. However, the exact proportions of $\mathrm{D}$ - or $\mathrm{L}-\left[{ }^{3} \mathrm{H}\right] \operatorname{Ins}(1,2,4,5,6) P_{5}$ in the original extract cannot be assessed, as the stereoselectivity of the Aspergillus phytase for, and hence the relative rates of attack on, D- or L-Ins $(1,2,4,5,6) P_{5}$ are unknown (it is unlikely to be highly 
Table 2. Subcellular distribution of $\left.D-\left.\right|^{3} \mathrm{H}\right] \operatorname{Ins}(1,2,4,5,6) P_{5}$ hydroxy kinase in Dictyostelium

A suspension of Dictyostelium was homogenized by filtration. A soluble fraction was prepared from this by centrifugation $(100000 \mathrm{~g}$, $90 \mathrm{~min}, 4^{\circ} \mathrm{C}$ ) and the pellet was resuspended in lysis buffer to the volume of the original filtrate to yield a particulate fraction. Triton $\mathrm{X}-114$ was added to portions of each of the fractions (final concn. $0.2 \%, \mathrm{w} / \mathrm{v}$ ), and samples of all the fractions were diluted 200 -fold into $25 \mathrm{~mm}$-Hepes / $1 \mathrm{~mm}$-EGTA / $1 \mathrm{~mm}$-dithiothreitol / $1 \mathrm{mg}$ of $\mathrm{BSA} / \mathrm{ml}\left(\mathrm{pH} 7.0,4^{\circ} \mathrm{C}\right)$ and assayed for $\left[{ }^{3} \mathrm{H}\right] \operatorname{Ins}(1,2,4,5,6) P_{5}$ hydroxy kinase activity as described in the Materials and methods section. The assays each contained 20000 d.p.m. of $\mathrm{D} / \mathrm{L}-\left[{ }^{3} \mathrm{H}\right] \operatorname{Ins}(1,2,4,5,6) P_{5}$. The data are means $(n=2)$ from a single experiment which was representative of two other similar experiments.

\begin{tabular}{lc}
\hline Treatment & $\begin{array}{c}\% \text { of total }{ }^{3} \mathrm{H} \text { in assay } \\
\text { in }{ }^{3} \mathrm{H}-\text { Ins } P_{6}\end{array}$ \\
\hline No enzyme & 0 \\
Filtrate & 12.6 \\
Filtrate $+\mathrm{X}-114$ & 12.8 \\
Particulate & 1.0 \\
Particulate $+\mathrm{X}-114$ & 0.8 \\
Soluble & 11.5 \\
Soluble $+\mathrm{X}-114$ & 10.9
\end{tabular}

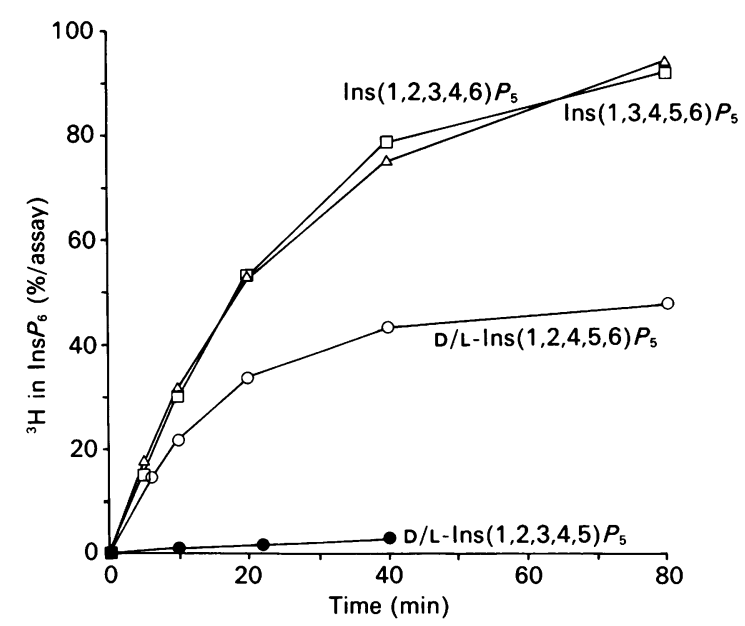

Fig. 7. Phosphorylation of $\left[{ }^{3} \mathrm{H}\right]$ Ins $\boldsymbol{P}_{5} \mathrm{~s}$ in slime-mould cytosolic fractions

A cytosolic fraction was prepared from Dictyostelium NC4 amoebae and diluted to various extents into $25 \mathrm{~mm}$-Hepes/1 mM-EGTA/ $1 \mathrm{~mm}$-dithiothreitol $/ 1 \mathrm{mg}$ of $\mathrm{BSA} / \mathrm{ml}\left(\mathrm{pH} 7.0,4^{\circ} \mathrm{C}\right)$. Samples $(150 \mu \mathrm{l})$ of the appropriate dilutions of the crude cytosol fraction were incubated with standard $\left[{ }^{3} \mathrm{H}\right] \mathrm{Ins} P_{5}$ s (all approx. $60 \mathrm{Ci} / \mathrm{mmol}$ ) for various times (in assays of $200 \mu \mathrm{l}$ total volume). D/L$\left[{ }^{3} \mathrm{H}\right] \operatorname{Ins}(1,2,4,5,6) P_{5}(O ; 90000$ d.p.m./assay) was incubated with a 200 -fold dilution of crude cytosol; $\left[{ }^{3} \mathrm{H}\right] \operatorname{Ins}(1,3,4,5,6) P_{5}(\triangle$; 50000 d.p.m./assay) was incubated with a 10-fold dilution of crude cytosol; $\left[{ }^{3} \mathrm{H}\right] \operatorname{Ins}(1,2,3,4,6) P_{5}(\square ; 45000$ d.p.m./assay) was incubated with a 40 -fold dilution of crude cytosol; and D/L- $\left[{ }^{3} \mathrm{H}\right] \operatorname{Ins}(1,2,3,4,5) P_{5}$ (O; 100000 d.p.m./assay) was incubated with undiluted crude cytosol. The assay constituents and sample analysis were as described in the Materials and methods section. The data are presented as the mean $(n=2)$ percentage of the total ${ }^{3} \mathrm{H}$ (d.p.m.) in the assay that was recovered as $\left[{ }^{3} \mathrm{H}\right] \mathrm{Ins} P_{6}$. The results are typical of three similar experiments.

selective, as it is capable of dephosphorylating at least three other $\left[{ }^{3} \mathrm{H}\right] \mathrm{Ins} \boldsymbol{P}_{5}$ s as well as $\left[{ }^{3} \mathrm{H}\right] \mathrm{Ins} \boldsymbol{P}_{6} ; \quad$ L. R. Stephens, unpublished work). This was the only evidence that we obtained that was consistent with the presence of any $\mathrm{L}-\left[{ }^{3} \mathrm{H}\right] \mathrm{Ins}(1,2,4,5,6) P_{5}$ in NC4 amoebae, and furthermore numerous independent preparations

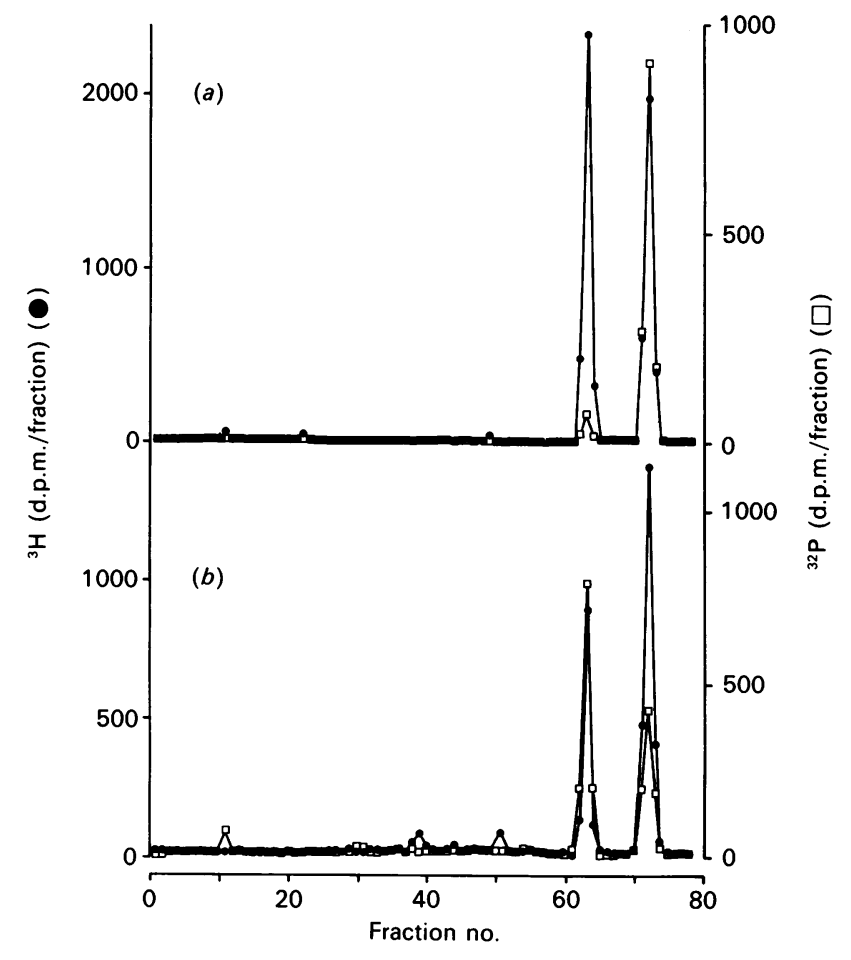

Fig. 8. Substrate specificity of a Dictyostelium $\operatorname{Ins}(1,2,4,5,6) P_{5}$ hydroxy kinase activity

A suspension of NC4 amoebae was permeabilized by electroporation and incubated for 0 min (results not shown) or $40 \mathrm{~min}$ with mixtures of either $(a)\left[{ }^{32} \mathrm{P}\right] \operatorname{Ins}(1,2,4,5,6) P_{5}(\square$, D- and/or L; h.p.l.c.-purified from [ $\left.{ }^{32} \mathrm{P}\right] \mathrm{P}_{1}$-labelled $\mathrm{NC} 4$ amoebae) and $\mathrm{D} / \mathrm{L}-$ $\left[{ }^{3} \mathrm{H}\right] \operatorname{Ins}(1,2,4,5,6) P_{5}(\odot$, racemic $)$, or $(b)\left[{ }^{3} \mathrm{H}\right] \operatorname{Ins}(1,2,4,5,6) P_{5}(\odot$; derived from $\left[{ }^{3} \mathrm{H}\right]$ Ins $P_{6}$ through the action of an Aspergillus phytase) and $\mathrm{D} / \mathrm{L}-\left[{ }^{32} \mathrm{P}\right] \operatorname{Ins}(1,2,4,5,6) P_{5}(\square$, racemic): see the Materials and methods section for details. The assays were quenched, processed and chromatographed on a Partisphere SAX h.p.l.c. column as described in the Materials and methods section. The eluate was collected into fractions which were counted for ${ }^{3} \mathrm{H}$ and ${ }^{32} \mathrm{P}$ radioactivity as described. The results are typical of those obtained with two independent preparations of $\left[{ }^{32} \mathrm{P}\right] \operatorname{Ins}(1,2,4,5,6) P_{5}$ (from amoebae) and three preparations of $\left[{ }^{3} \mathrm{H}\right] \operatorname{Ins}(1,2,4,5,6) P_{5}$ (produced by the Aspergillus phytase). The zero-time incubations all contained a single peak of ${ }^{3} \mathrm{H}$ and ${ }^{32} \mathrm{P}$ radioactivity which was eluted at the time expected for $\mathrm{D} / \mathrm{L}-\mathrm{Ins}(1,2,4,5,6) P_{5}$.

of D- and/or L- $\left[{ }^{3} \mathrm{H}\right] \operatorname{Ins}(1,2,4,5,6) P_{5}$ from $\left[{ }^{3} \mathrm{H}\right]$ Ins-prelabelled amoebae appeared completely homogeneous when assayed with a kinase that is totally selective for D-Ins $(1,2,4,5,6) P_{5}$ (see below).

\section{Ins $\boldsymbol{P}_{5}$ kinase activities in amoebae}

When $\left[{ }^{3} \mathrm{H}\right] \operatorname{Ins}(1,3,4,5,6) P_{5},\left[{ }^{3} \mathrm{H}\right] \operatorname{Ins}(1,2,3,4,6) P_{5}, \mathrm{D} / \mathrm{L}-\left[{ }^{3} \mathrm{H}\right]$ Ins$(1,2,4,5,6) P_{5}$ and $\mathrm{D} / \mathrm{L}-\left[{ }^{3} \mathrm{H}\right] \operatorname{Ins}(1,2,3,4,5) P_{5}$ (all $\left.60 \mathrm{Ci} / \mathrm{mmol}\right)$ were incubated with amoebae homogenates in the presence of ATP, then $\left[{ }^{3} \mathrm{H}\right] \mathrm{Ins} P_{6}$ was formed in assays containing any of the first three substrates. The Ins $P_{5}$ kinase activities were soluble and showed no significant latency (see Table 2, and results not shown). By diluting cytosolic fractions (into $25 \mathrm{~mm}-\mathrm{Hepes} / 1 \mathrm{mM}-$ EGTA/1 mM-dithiothreitol/1 mg of $\mathrm{BSA} / \mathrm{ml}, \mathrm{pH} 7.0,4^{\circ} \mathrm{C}$ ), it was possible to construct assays which operated under first-order conditions with respect to the quantity of enzyme added. If the progress of these reactions was monitored with time, it was apparent that both $\left[{ }^{3} \mathrm{H}\right] \operatorname{Ins}(1,3,4,5,6) P_{5}$ and $\left[{ }^{3} \mathrm{H}\right] \operatorname{Ins}(1,2,3,4,6) P_{5}$ could be completely phosphorylated to $\left[{ }^{3} \mathrm{H}\right] \operatorname{Ins} P_{6}$, whereas a maximum of $49-52 \%$ of several independent $\mathrm{D} / \mathrm{L}-\left[{ }^{3} \mathrm{H}\right]-$ Ins $(1,2,4,5,6) P_{5}$ preparations gave $\left[{ }^{3} \mathrm{H}\right] \mathrm{Ins} P_{6}$ (less than $5 \%$ of 
a sample of $\left[{ }^{3} \mathrm{H}\right] \operatorname{Ins} P_{6}$ was dephosphorylated in any of a set of parallel assays which were run under identical conditions; see Fig. 7). The substrate specificity of the kinase activity which could phosphorylate approx. $50 \%$ of a D/L- $\left[{ }^{3} \mathrm{H}\right] \operatorname{Ins}(1,2,4,5,6) P_{5}$ preparation was investigated by incubating with amoebae homogenates or cytosolic fractions: $(a)$ a mixture of $\left[{ }^{32} \mathrm{P}\right]-\mathrm{D}-$ and/or L-Ins $(1,2,4,5,6) P_{5}$ (derived from $\left[{ }^{32} \mathrm{P}\right] \mathrm{P}_{\mathrm{i}}$-prelabelled amoebae) and racemic D/L- $\left[{ }^{3} \mathrm{H}\right] \operatorname{Ins}(1,2,4,5,6) P_{5}$ or $(b)$ a mixture of D- and/or L$\left[{ }^{3} \mathrm{H}\right] \mathrm{Ins}(1,2,4,5,6) P_{5}$ derived from $\left[{ }^{3} \mathrm{H}\right] \mathrm{Ins} P_{6}$ through the action of a commercially available Aspergillus phytase preparation (see above; its enantiomeric configuration is uncertain) and racemic D/L-Ins $\left[{ }^{32} \mathrm{P}\right](1,2,4,5,6) P_{5}$. The assays were constructed so that the reactions were expected to reach around $50 \%$ conversion of the racemic substrates (see Fig. 8). Some $66 \%$ of the D- and/or L$\left[{ }^{3} \mathrm{H}\right] \operatorname{Ins}(1,2,4,5,6) P_{5}$ produced by the Aspergillus phytase preparation was phosphorylated to $\left[{ }^{3} \mathrm{H}\right] \operatorname{Ins} P_{6}$ in an assay in which $38 \%$ of the total D/L-Ins $\left.{ }^{32} \mathrm{P}\right](1,2,4,5,6) P_{5}$ was phosphorylated to Ins $\left[{ }^{32} \mathrm{P}\right] P_{6}$; extrapolating the extent of reaction to the point where $50 \%$ of the total racemic mixture would have been phosphorylated predicts that $87 \%$ of the total $\left[{ }^{3} \mathrm{H}\right]$ Ins$(1,2,4,5,6) P_{5}$ was the $\mathrm{D}$ isomer. The slime-mould-derived D- and/or L-Ins $\left[{ }^{32} \mathrm{P}\right](1,2,4,5,6) P_{5}$ was completely converted into Ins $\left[{ }^{32} \mathrm{P}\right] P_{6}$ (see Fig. 8 ), whereas only $49 \%$ of the racemic D/L$\left[{ }^{3} \mathrm{H}\right] \operatorname{Ins}(1,2,4,5,6) P_{5}$ was converted into $\left[{ }^{3} \mathrm{H}\right] \operatorname{Ins} P_{6}$. These results show that: (i) the slime-mould $\operatorname{Ins}\left[{ }^{32} \mathrm{P}\right](1,2,4,5,6) P_{5}$ is homogeneous (i.e. all $D$ or $L$ ), (ii) the kinase responsible for its conversion into Ins $\left[{ }^{32} \mathrm{P}\right] P_{6}$ is completely selective for that isomer, and (iii) approx. $8 \%$ of the Aspergillus phytase product is of the same stereochemical configuration as the slime-mould-derived Ins $P_{5}$.

On the basis of the data presented in the previous section, we have suggested that the slime-mould-derived $\operatorname{Ins}(1,2,4,5,6) P_{5}$ is predominantly the D-enantiomer, though we could not rule out some L-isomer being present. The results discussed in the preceding paragraph suggest it is in fact a pure enantiomer, and therefore we conclude that it is $\mathrm{D}-\operatorname{Ins}(1,2,4,5,6) P_{5}$. The data above also show that the fungal phytase product is largely $D$ Ins $(1,2,4,5,6) P_{5}$ as previous data did not establish the precise proportions of the $\mathrm{D}$ - and L-enantiomers present, only that there was more of the D-isomer (Irving \& Cosgrove, 1972). Hence, altogether these results independently confirm (a) that the Dictyostelium-derived activity capable of phosphorylating D- or L-Ins $(1,2,4,5,6) P_{5}$ is in fact a D-Ins $(1,2,4,5,6) P_{5} 3$-hydroxy kinase and $(b)$ that the slime-mould-derived $\left[{ }^{3} \mathrm{H}\right] \operatorname{Ins}(1,2,4,5,6) P_{5}$ is the Denantiomer, and furthermore, that $87 \%$ of the D- and/or LIns $(1,2,4,5,6) P_{5}$ that had accumulated in the Aspergillus-phytasecatalysed dephosphorylation mixture was of the D-configuration.

The first-order rate constants for the conversion of Ins $(1,3,4,5,6) P_{5}, \operatorname{Ins}(1,2,3,4,6) P_{5}$ and $\mathrm{D}$-Ins $(1,2,4,5,6) P_{5}$ into Ins $P_{6}$ in intact amoebae were estimated by extrapolating data from assays with diluted cytosol fractions; they were $0.1,0.8$ and $3.1 \mathrm{~s}^{-1}$ respectively [assuming (a) a cytosolic protein concentration of $50 \mathrm{mg} / \mathrm{ml}$ and $(b)$ only half of a racemic mixture of D/L-[ $\left.{ }^{3} \mathrm{H}\right] \operatorname{Ins}(1,2,4,5,6) P_{5}$ represented potential substrate].

\section{Ins $P_{5}$ kinase activities in rat brain}

We also searched for $\left[{ }^{3} \mathrm{H}\right] \mathrm{Ins} P_{5}$ kinase activities in rat brain extracts. We found soluble, ATP-dependent, heat-labile activities capable of converting all four chromatographic classes of $\left[{ }^{3} \mathrm{H}\right] \operatorname{Ins} P_{5}$ into $\left[{ }^{3} \mathrm{H}\right] \operatorname{Ins} P_{6} . \quad$ D $/ \mathrm{L}-\left[{ }^{3} \mathrm{H}\right] \operatorname{Ins}(1,2,4,5,6) P_{5}, \quad \mathrm{D} / \mathrm{L}-$ $\left[{ }^{3} \mathrm{H}\right] \operatorname{Ins}(1,2,3,4,5) P_{5},\left[{ }^{3} \mathrm{H}\right] \operatorname{Ins}(1,2,3,4,6) P_{5}$ and $\left[{ }^{3} \mathrm{H}\right] \operatorname{Ins}(1,3,4,5,6) P_{5}$ were converted into $\left[{ }^{3} \mathrm{H}\right] \mathrm{Ins} P_{6}$ with initial rates, expressed as the percentage of total radioactivity in the assay appearing as $\left[{ }^{3} \mathrm{H}\right] \mathrm{Ins} \boldsymbol{P}_{6}$, of $1.3,0.7,2.7$ and approx. $0.05 \% / \mathrm{min}$ respectively, with a soluble protein concentration of $3.42 \pm 0.5 \mathrm{mg} / \mathrm{ml}$ in the assays (Fig. 9, and results not shown). The conversion of all

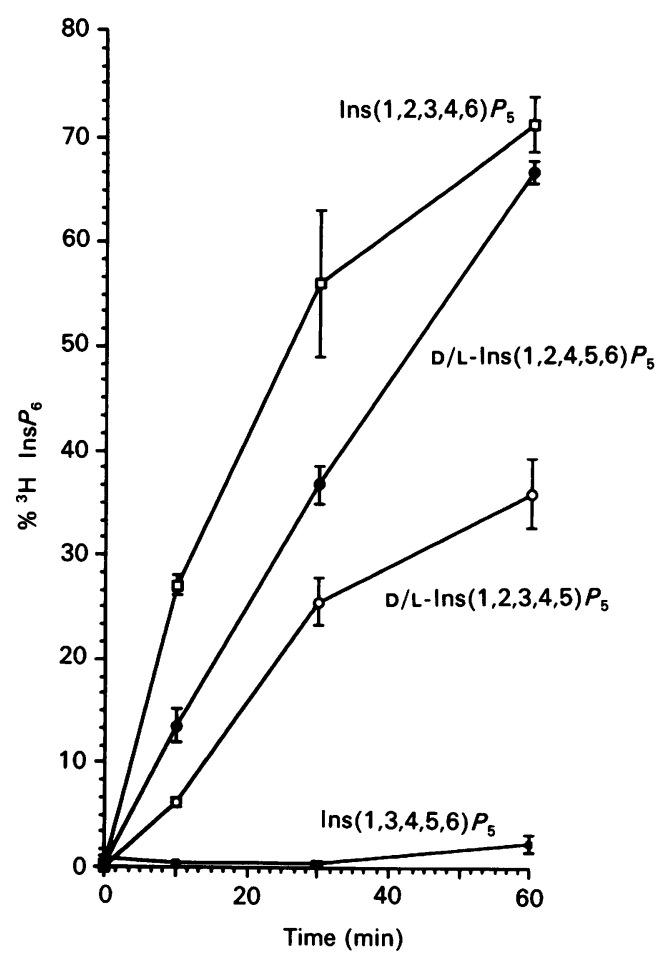

Fig. 9. Phosphorylation of $\left[{ }^{3} \mathrm{H}\right]$ Ins $P_{5} \mathrm{~s}$ in rat brain cytosolic fractions

A cytosolic fraction was prepared from rat brain as described in the Materials and methods section ( $3.57 \mathrm{~g}$ wet wt./ $10.0 \mathrm{ml}$ of buffer). Portions $(150 \mu \mathrm{l})$ of the undiluted cytosol fraction were incubated with standard $\left[{ }^{3} \mathrm{H}\right] \operatorname{Ins} P_{5} \mathrm{~s}$ in a total volume of $250 \mu \mathrm{l}$ for various times (see the Materials and methods section). Approx. 20000 d.p.m. of each $\left[{ }^{3} \mathrm{H}\right] \mathrm{Ins} P_{5}(80 \mathrm{Ci} / \mathrm{mmol}$, made from alkali-catalysed hydrolysis of $\left.\left[{ }^{3} \mathrm{H}\right] \operatorname{Ins} P_{6}\right)$ was used per assay: $\left[{ }^{3} \mathrm{H}\right] \operatorname{Ins}(1,3,4,5,6) P_{5}(\square)$, $\left[{ }^{3} \mathrm{H}\right] \operatorname{Ins}(1,2,3,4,6) P_{5}(\square), \mathrm{D} / \mathrm{L}-\left[{ }^{3} \mathrm{H}\right] \operatorname{Ins}(1,2,4,5,6) P_{5}(\bigcirc)$ or $\mathrm{D} / \mathrm{L}-$ $\left[{ }^{3} \mathrm{H}\right] \operatorname{Ins}(1,2,3,4,5) P_{5}(O)$. The assay constituents and sample analysis were as described in the Materials and methods section. The data are presented as the mean percentages $( \pm$ S.D.; $n=3)$ of the total ${ }^{3} \mathrm{H}$ in the assay that was recovered as $\left[{ }^{3} \mathrm{H}\right] \mathrm{Ins} P_{6}$. The results are typical of three similar experiments (including one in which the $\left[{ }^{3} \mathrm{H}\right] \mathrm{Ins} P_{5}$ substrates were purified directly from the mixture of $\left[{ }^{3} \mathrm{H}\right] \mathrm{Ins}$ polyphosphates produced during the phosphorylation of $\left[{ }^{3} \mathrm{H}\right] \mathrm{Ins}$; see the Materials and methods section).

$\left[{ }^{3} \mathrm{H}\right] \mathrm{Ins} P_{5}$ isomers into $\left[{ }^{3} \mathrm{H}\right] \operatorname{Ins} P_{6}$ proceeded with no apparent lag and, under the assay conditions employed, $\left[{ }^{3} \mathrm{H}\right] \mathrm{Ins} P_{6}$ and each of the $\left[{ }^{3} \mathrm{H}\right] \operatorname{Ins} P_{5}$ isomers were dephosphorylated very slowly; less than $5 \%$ of $\left[{ }^{3} \mathrm{H}\right] \mathrm{Ins} P_{6}$, at the same actual concentration as the $\left[{ }^{3} \mathrm{H}\right]$ Ins $P_{5}$ isomers, was dephosphorylated in $120 \mathrm{~min}$ (results not shown). We have not yet defined the relative rates of conversion for each enantiomer within each of the two racemic pairs of Ins $P_{5}$ isomers. It is clear, however, that over $50 \%$ conversion of $\mathrm{D} / \mathrm{L}-$ $\left[{ }^{3} \mathrm{H}\right] \operatorname{Ins}(1,2,4,5,6) P_{5}$ into $\left[{ }^{3} \mathrm{H}\right] \operatorname{Ins} P_{6}$ can be seen with prolonged incubations (Fig. 9), and therefore both D- and L$\left[{ }^{3} \mathrm{H}\right] \operatorname{Ins}(1,2,4,5,6) P_{5}$ must act as substrates for $\operatorname{Ins} P_{5}$ kinase activities in rat brain cytosol. We could detect no Ins $P_{5}$ hydroxy kinase activities in rat brain particulate fractions, though the rate of dephosphorylation of each $\left[{ }^{3} \mathrm{H}\right] \mathrm{Ins} P_{5}$ isomer was increased relative to cytosol fractions $\left\{\mathrm{D} / \mathrm{L}-\left[{ }^{3} \mathrm{H}\right] \operatorname{Ins}(1,2,3,4,5) P_{5}\right.$ was the most actively dephosphorylated isomer; results not shown\}.

\section{Ins $\boldsymbol{P}_{\mathbf{5}}$ kinase activities in mung bean}

$\left[{ }^{3} \mathrm{H}\right] \mathrm{Ins} P_{5}$ kinase assays were also performed with mung-bean seedling cytosolic fractions. High-speed supernatants prepared from seedling homogenates could phosphorylate all four chromatographic classes of $\left[{ }^{3} \mathrm{H}\right] \operatorname{Ins} P_{5}:\left[{ }^{3} \mathrm{H}\right] \operatorname{Ins}(1,3,4,5,6) P_{5}$, 


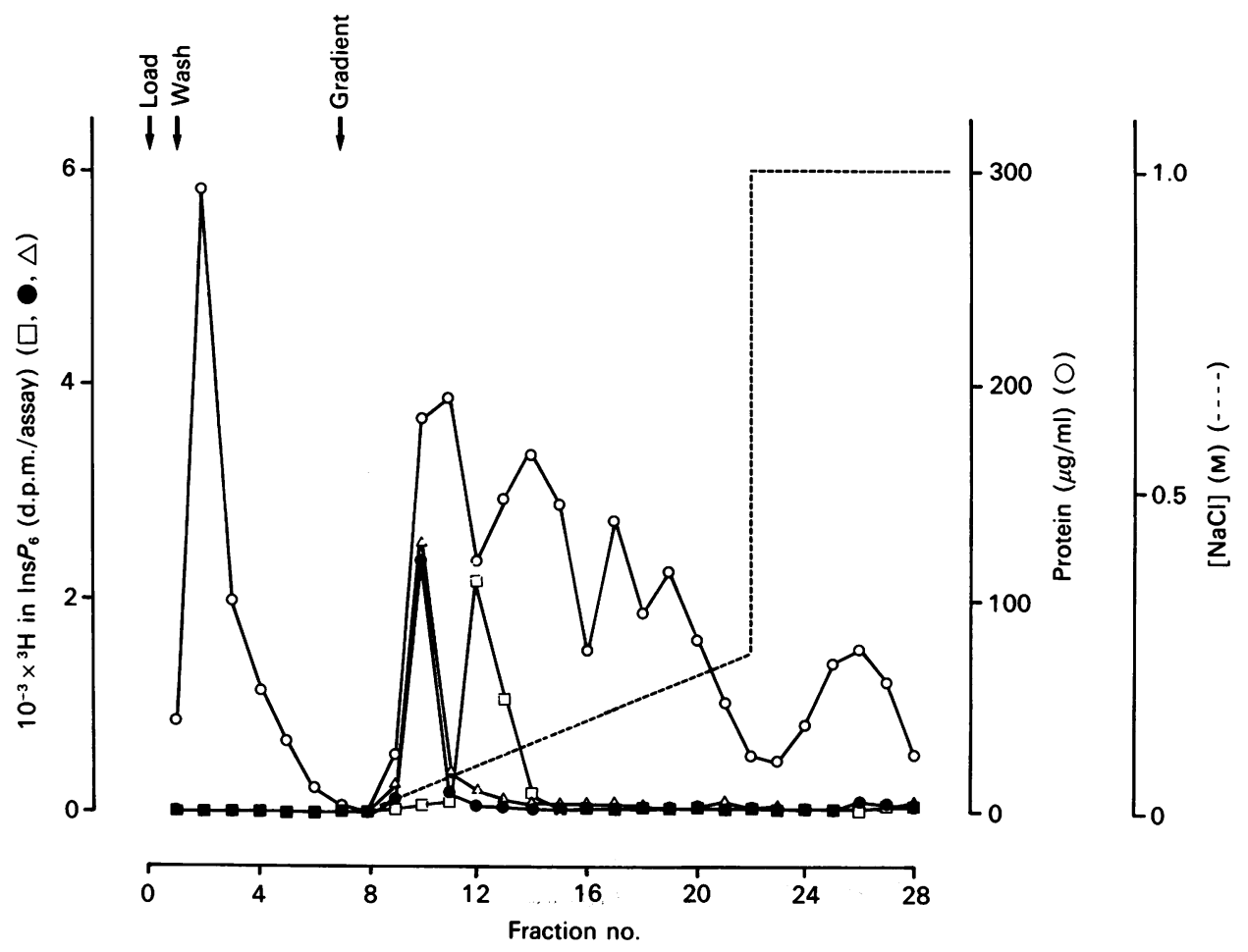

Fig. 10. Resolution of Dictyostelium Ins $\boldsymbol{P}_{5}$ hydroxy kinase activities on DEAE-Sepharose

Dictyostelium cytosolic fraction ( $4 \mathrm{ml}$ containing $11 \mathrm{mg}$ of total protein; see the Materials and methods section) was loaded on a $4 \mathrm{ml}$ column of DEAE-Sepharose at a flow rate of $1 \mathrm{ml} / \mathrm{min}$. The column was washed with buffer A ( $25 \mathrm{~mm}$-Hepes/1 mM-EGTA/1 mM-dithiothreitol, pH 7.0, $4{ }^{\circ} \mathrm{C}$ ) and eluted with a NaCl gradient (in buffer $\mathrm{A}$, as indicated in the Figure; ----). Fractions were collected every 4 min and samples were assayed for protein $(O)$ and for $\left[{ }^{3} \mathrm{H}\right] \operatorname{Ins}(1,3,4,5,6) P_{5}$ kinase $\left(\square ; 100 \mu \mathrm{l}\right.$ of a 10 -fold dilution of each fraction in $200 \mu 1$ assays), $\left[{ }^{3} \mathrm{H}\right] \operatorname{Ins}(1,2,3,4,6) P_{5}$ kinase (O; $100 \mu \mathrm{l}$ of a 30 -fold dilution of each fraction in $200 \mu \mathrm{l}$ assays), and $\left[{ }^{3} \mathrm{H}\right] \operatorname{Ins}(1,2,4,5,6) P_{5}$ kinase $(\triangle ; 100 \mu 1$ of a 500 -fold dilution of each fraction in $200 \mu \mathrm{l}$ assays). The assays were run for $30 \mathrm{~min}$, then quenched, mixed with $\left[{ }^{32} \mathrm{P}\right] \mathrm{Ins} P_{6}$ and resolved into $\left[{ }^{3} \mathrm{H}\right] \mathrm{Ins} P_{5}$ and $\left[{ }^{3} \mathrm{H}\right] \mathrm{Ins} P_{6}$ fractions as described in the Materials and methods section. The data shown are typical of three independent separations: $102 \%$ of the $\left[{ }^{3} \mathrm{H}\right] \mathrm{Ins}(1,3,4,5,6) P_{5}$ kinase, $83 \%$ of the $\mathrm{D}-\left[{ }^{3} \mathrm{H}\right] \operatorname{Ins}(1,2,4,5,6) P_{5}$ kinase and $85 \%$ of the $\left[{ }^{3} \mathrm{H}\right] \operatorname{Ins}(1,2,3,4,6) P_{5}$ kinase activities that were applied to the column were recovered.

$\left[{ }^{3} \mathrm{H}\right] \operatorname{Ins}(1,2,3,4,6) P_{5}, \quad$ D/L- $\left[{ }^{3} \mathrm{H}\right] \operatorname{Ins}(1,2,4,5,6) P_{5} \quad$ and $\quad \mathrm{D} / \mathrm{L}-$ $\left[{ }^{3} \mathrm{H}\right] \operatorname{Ins}(1,2,3,4,5) P_{5}$ were phosphorylated with first-order rate constants of $0.0066,0.0024,0.0002$ and $0.0022 \mathrm{~s}^{-1}$ respectively, in an undiluted supernatant derived from $9.7 \mathrm{~g}$ of wet germinated mung beans homogenized into $10 \mathrm{ml}$ of buffer at a protein concentration of $10 \mathrm{mg} / \mathrm{ml}$ (see the Materials and methods section). These rate constants are derived from experiments with supernatant fractions (diluted 50-500-fold into $25 \mathrm{~mm}$ Hepes / $1 \mathrm{~mm}$-EGTA / $1 \mathrm{~mm}$-dithiothreitol $/ 1 \mathrm{mg}$ of $\mathrm{BSA} / \mathrm{ml}$,

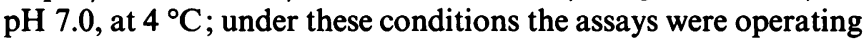
under first-order conditions with respect to added mung-bean protein), and then extrapolated to yield estimates of the rates in the original lysate.

The Dictyostelium D-Ins $(1,2,4,5,6) P_{5}$ hydroxy kinase activity was used to establish the stereochemical configuration of D- and/or L-Ins $\left[{ }^{32} \mathrm{P}\right](1,2,4,5,6) P_{5}$ derived from $\left[{ }^{32} \mathrm{P}\right] \mathrm{P}_{1}$-labelled mung-bean seedlings (as above); $79 \%$ of the total $\mathrm{D}$ - and/or L-Ins $\left.{ }^{32} \mathrm{P}\right](1,2,4,5,6) P_{5}$ was of the $\mathrm{L}$ configuration (results not shown).

\section{Resolution of Ins $P_{5}$ kinase activities in slime moulds}

The $\left[{ }^{3} \mathrm{H}\right]$ Ins $P_{5}$ kinase activities in slime-mould cytosol fractions could be resolved into two peaks by chromatography on DEAESepharose: [ $\left.{ }^{3} \mathrm{H}\right] \operatorname{Ins}(1,3,4,5,6) P_{5}$ hydroxy kinase was eluted significantly after $\left[{ }^{3} \mathrm{H}\right] \operatorname{Ins}(1,2,3,4,6) P_{5}$ and $\mathrm{D}-\left[{ }^{3} \mathrm{H}\right] \operatorname{Ins}(1,2,4,5,6) P_{5}$ hydroxy kinase activities (see Fig. 10). Furthermore, the effects of a range of inositol polyphosphates on the activity of the three Ins $P_{5}$ hydroxy kinase activities in crude slime-mould cytosolic fractions allowed at least two functionally independent kinases to be resolved (see Fig. 11). $\left[{ }^{3} \mathrm{H}\right] \operatorname{Ins}(1,3,4,5,6) P_{5}$ hydroxy kinase showed a completely different pattern of response compared with $\left[{ }^{3} \mathrm{H}\right] \operatorname{Ins}(1,2,3,4,6) P_{5}$ and $\mathrm{D}-\left[{ }^{3} \mathrm{H}\right] \operatorname{Ins}(1,2,4,5,6) P_{5}$ hydroxy kinases. It should be noted that, in the $\left[{ }^{3} \mathrm{H}\right] \operatorname{Ins}(1,3,4,5,6) P_{5}$ hydroxy kinase assays to which small amounts of $\operatorname{Ins}(1,2,3,4,6) P_{5}$ and D/L-Ins $(1,2,4,5,6) P_{5}$ had been added, significant fractions of the cold inositol phosphates would have been converted into Ins $P_{6}$; similarly large proportions of the lower concentrations of $\mathrm{D} / \mathrm{L}$ Ins $(1,2,4,5,6) P_{5}$ added to the $\left[{ }^{3} \mathrm{H}\right] \operatorname{Ins}(1,2,3,4,6) P_{5}$ hydroxy kinase would have been converted into Ins $P_{6}$. However, the fact that the inhibition curves deviate substantially from those of $\operatorname{Ins} P_{6}$ (both positively and negatively) shows that this problem is not too severe, and is limited by the low $K_{\mathrm{m}}$ values of these activities for their substrates (see below). The $K_{\mathrm{m}}$ values of the $\left[{ }^{3} \mathrm{H}\right]$ $\operatorname{Ins}(1,2,3,4,6) P_{5},\left[{ }^{3} \mathrm{H}\right] \operatorname{Ins}(1,3,4,5,6) P_{5}$ and $\mathrm{D}-\left[{ }^{3} \mathrm{H}\right] \operatorname{Ins}(1,2,4,5,6) P_{5}$ hydroxy kinase activities in slime-mould cytosolic fractions were determined to be $3.8 \mu \mathrm{M}, 1.6 \mu \mathrm{M}$ and $1.4 \mu \mathrm{M}$ respectively (see Fig. 12).

\section{Levels of $\operatorname{Ins} \boldsymbol{P}_{6}$ and the $\operatorname{Ins} \boldsymbol{P}_{5}$ hydroxy kinase activities during} differentiation of Dictyostelium

Amoebae were harvested from exponentially growing populations of cells and plated out on agar supports in the absence of nutrients to develop into fruiting bodies. Samples of cells were harvested at intervals, and acid extracts were prepared from some (see Fig. 13), whereas others were lysed with detergents and subsequently assayed for all three $\operatorname{Ins} P_{5}$ hydroxy kinase 


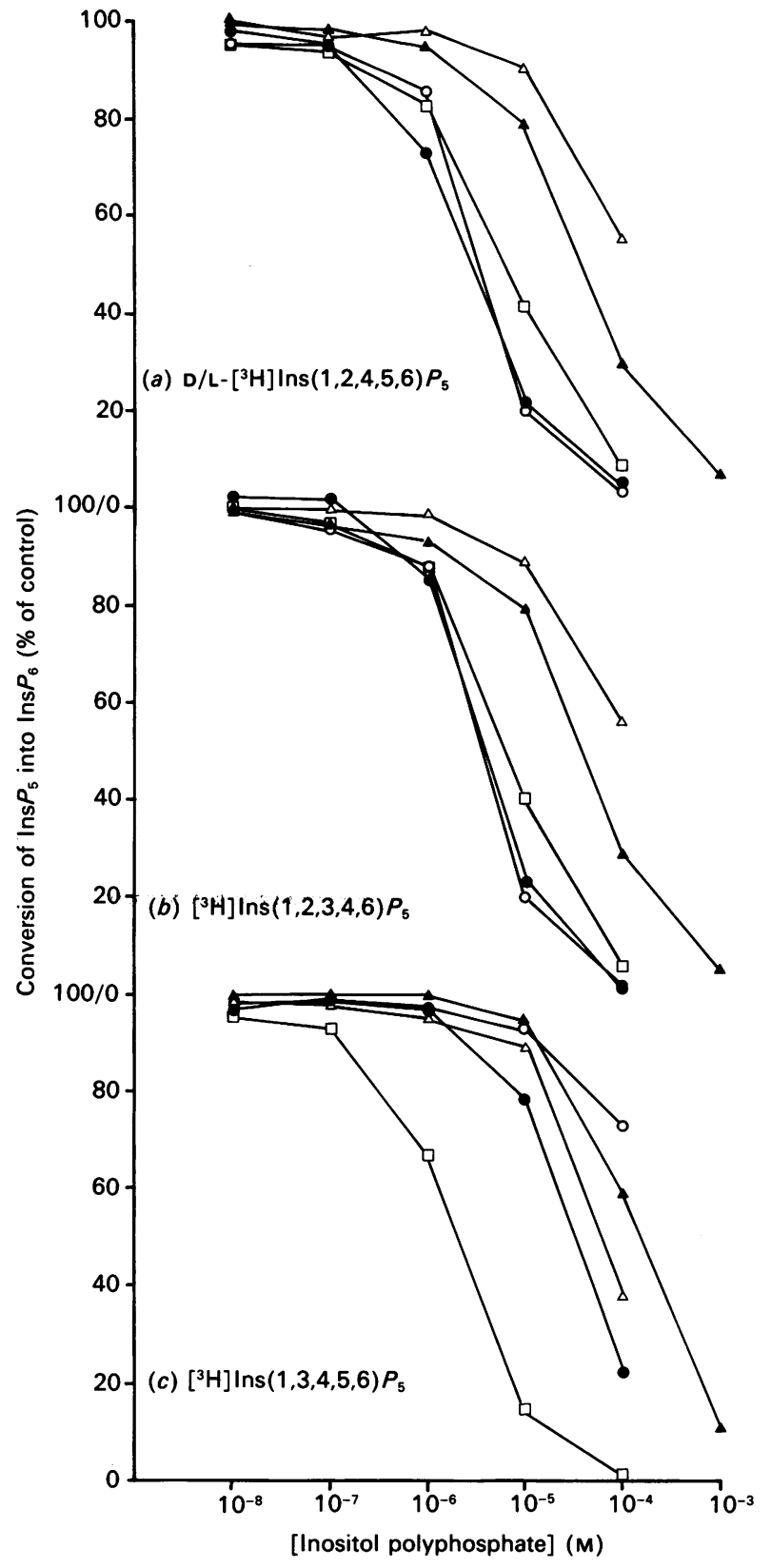

Fig. 11. Differential inhibition of the Dictyostelium $\left[^{3} \mathrm{H} \mid \mathrm{Ins} \boldsymbol{P}_{5}\right.$ hydroxy kinases with inositol polyphosphates

Dictyostelium-derived cytosolic fractions were diluted to various extents and assayed for $\mathrm{D}-\left[{ }^{3} \mathrm{H}\right] \operatorname{Ins}(1,2,4,5,6) P_{5}$ kinase $(a)$, $\left[{ }^{3} \mathrm{H}\right] \operatorname{Ins}(1,2,3,4,6) P_{5}$ kinase $(b)$ and $\left[{ }^{3} \mathrm{H}\right] \operatorname{Ins}(1,3,4,5,6) P_{5}$ kinase $(c)$ activities in the presence of a range of concentrations of $\operatorname{Ins} P_{6}(\boldsymbol{A})$, D/L-Ins $(1,2,3,4,5) P_{5}(\triangle), \mathrm{D} / \mathrm{L}-\operatorname{Ins}(1,2,4,5,6) P_{5}(\odot), \operatorname{Ins}(1,3,4,5,6) P_{5}$ (口) and $\mathrm{D} / \mathrm{L}$-Ins $(1,2,3,4,6) P_{5} \quad(O)$. The assays contained $50000-100000$ d.p.m. of substrate, of which a maximum of $22 \%$ was converted into $\left[{ }^{3} \mathrm{H}\right] \mathrm{Ins} P_{6}$ (a maximum of $10 \%$ of the total $\left[{ }^{3} \mathrm{H}\right] \operatorname{Ins}(1,2,4,5,6) P_{5}$ was converted into $\left.\left[{ }^{3} \mathrm{H}\right] \operatorname{Ins} P_{6}\right)$. Each point on the graphs is the mean of four determinations, pooled from two independent experiments (the mean S.D. was $3.1 \%$ ). The data are presented as proportions of the quantity of $\left[{ }^{3} \mathrm{H}\right] \mathrm{Ins} P_{5}$ converted into [ $\left.{ }^{3} \mathrm{H}\right]$ Ins $P_{6}$ in assays to which no inositol polyphosphates had been added.

activities and the marker enzymes cyclic AMP phosphodiesterase and glycogen phosphorylase (see the Materials and methods section). The concentration of $\operatorname{Ins} P_{6}$ in the acid extracts was determined by phosphorus assay of the fractions eluted from an h.p.l.c. column that contained the ${ }^{32} \mathrm{P}$ from a spike of $\operatorname{Ins}\left[{ }^{32} \mathrm{P}\right] P_{6}$
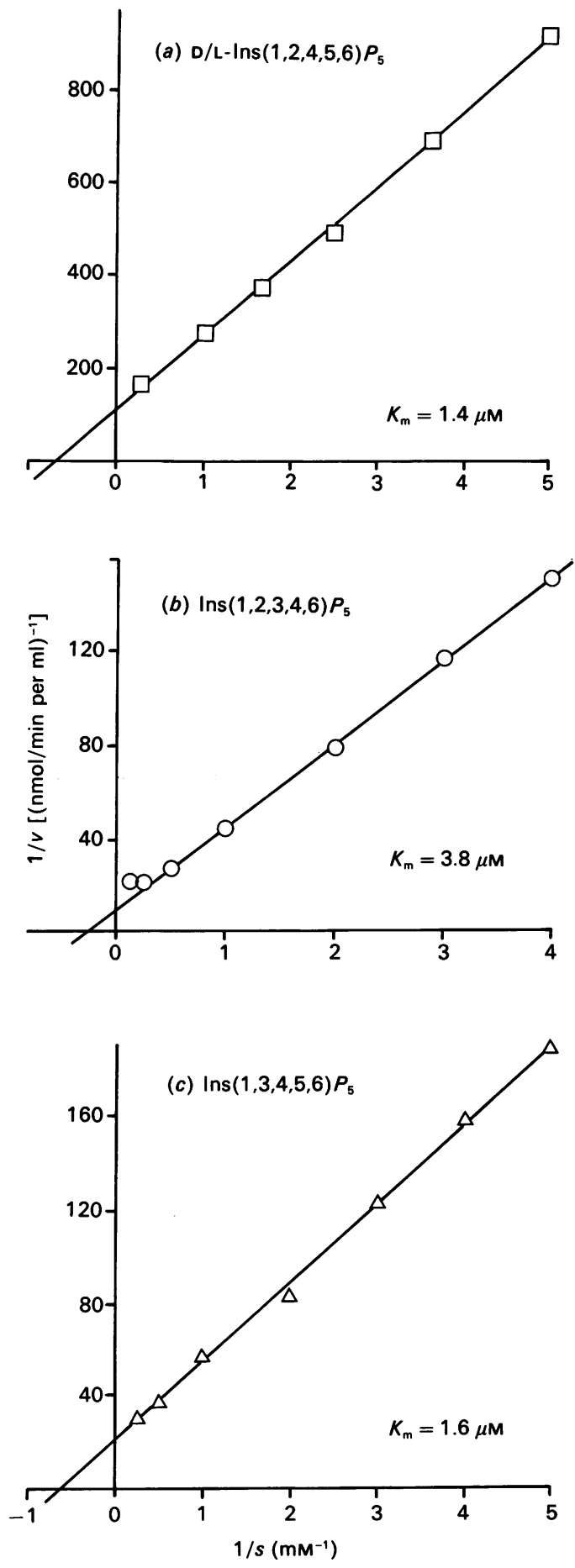

Fig. 12. Determination of the $K_{\mathrm{m}}$ values of the Dictyostelium $\left[{ }^{3} \mathrm{H}\right] \mathrm{Ins} \boldsymbol{P}_{5}$ hydroxy kinases for their $\operatorname{Ins} P_{5}$ substrates

Diluted Dictyostelium-derived cytosolic fractions were assayed for D- $\left[{ }^{3} \mathrm{H}\right] \operatorname{Ins}(1,2,4,5,6) P_{5}$ kinase $(a),\left[{ }^{3} \mathrm{H}\right] \operatorname{Ins}(1,2,3,4,6) P_{5}$ kinase $(b)$ and $\left[{ }^{3} \mathrm{H}\right] \operatorname{Ins}(1,3,4,5,6) P_{5}$ kinase $(c)$ as described in the Materials and methods section (and the legend to Fig. 11). A maximum of $20 \%$ of the radioactive substrate in any assay was converted into $\left[{ }^{3} \mathrm{H}\right] \mathrm{Ins} P_{6}$ (a maximum of $9 \%$ for the $\left[{ }^{3} \mathrm{H}\right] \mathrm{Ins}(1,2,4,5,6) P_{5}$ kinase assay). The data are means $(n=2)$ derived from single experiments (additional experiments yielded estimates of the $K_{\mathrm{m}}$ that are shown in parentheses below). The apparent $K_{\mathrm{m}}$ of Ins $(1,2,4,5,6) P_{5}$ hydroxy kinase for DIns $(1,2,4,5,6) P_{5}$ (assuming that only half of both the tritiated and unlabelled preparations of $\mathrm{D} / \mathrm{L}$-Ins $(1,2,4,5,6) P_{5}$ represented potential substrate) was $1.4 \mu \mathrm{M}(1.2 \mu \mathrm{M})$; that of $\left[{ }^{3} \mathrm{H}\right] \operatorname{Ins}(1,3,4,5,6) P_{5}$ hydroxy kinase for $\operatorname{Ins}(1,3,4,5,6) P_{5}$ was $1.6 \mu \mathrm{M}(1.7 \mu \mathrm{M})$; and that of $\left[{ }^{3} \mathrm{H}\right] \operatorname{Ins}(1,2,3,4,6) P_{5}$ hydroxy kinase for $\operatorname{Ins}(1,2,3,4,6) P_{5}$ was $3.8 \mu \mathrm{M}$ $(3.6 \mu \mathrm{M})$. 


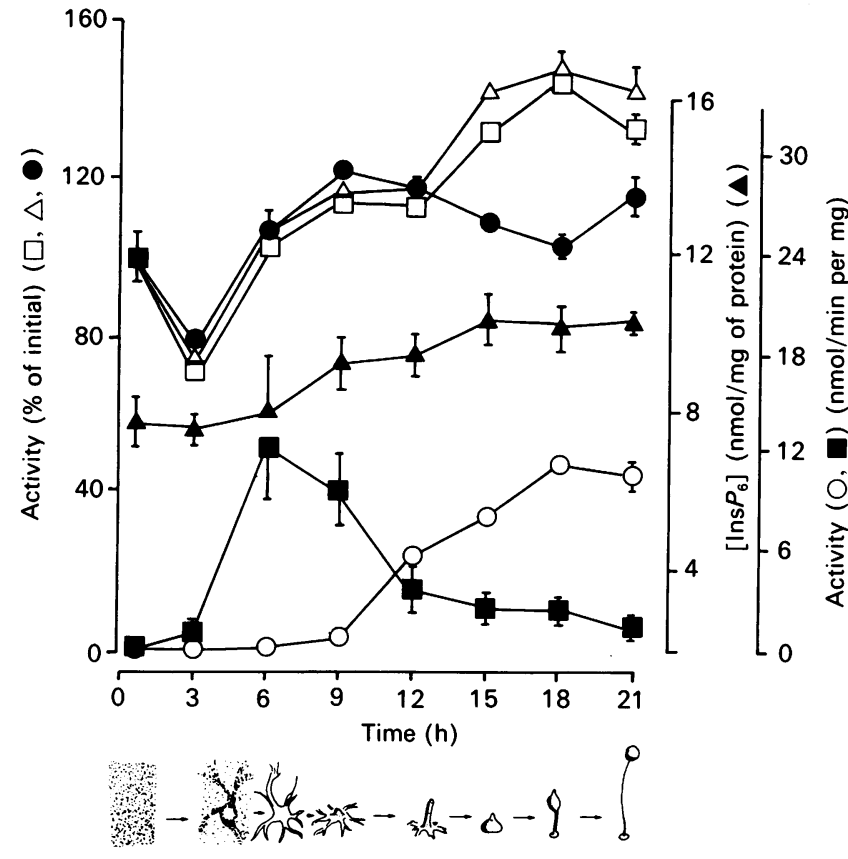

Fig. 13. Changes in the concentration of $\operatorname{Ins} P_{6}$ and in $\operatorname{Ins} P_{5}$ hydroxy kinase activities during development of Dictyostelium

An axenic strain of Dictyostelium (AX2) was starved of nutrients and plated out on solid agar supports to develop (see the Materials and methods section). Cells were harvested at various times to assay for Ins $P_{6}$ concentration $(\Delta)$, protein, cyclic AMP phosphodiesterase (ם), glycogen phosphorylase $(O)$ and $\left[{ }^{3} \mathrm{H}\right] \operatorname{Ins}(1,2,4,5,6) P_{5}(\triangle)$, $\left[{ }^{3} \mathrm{H}\right] \operatorname{Ins}(1,2,3,4,6) P_{5}(\square)$ and $\left[{ }^{3} \mathrm{H}\right] \operatorname{Ins}(1,3,4,5,6) P_{5}(\bigcirc)$ hydroxy kinase activities, as described in the Materials and methods section. A cartoon depiction of the approximate developmental stages of the organisms at the various times is given below the axis. Ins $P_{6}$ concentrations were determined in a separate set of experiments (with their associated glycogen phosphorylase and cyclic AMP phosphodiesterase assays) and are presented as means \pm S.E.M. $(n=3)$. The $\left[{ }^{3} \mathrm{H}\right] \operatorname{Ins} P_{5}$ kinase assays were performed on three independent sets of lysates each in duplicate; the data presented are based on means \pm S.E.M. $(n=6)$ expressed as a proportion of the activity detected in amoebae $(t=45 \mathrm{~min})$. The assays were performed under first-order conditions with respect to their $\left[{ }^{3} \mathrm{H}\right] \mathrm{Ins} P_{5}$ substrates exactly as described in the Materials and methods section (there was no significant dephosphorylation of internal $\left[{ }^{32} \mathrm{P}\right]$ Ins $P_{6}$ present in the assays). The activities measured in amoebae $(t=45 \mathrm{~min})$ were: $\left[{ }^{3} \mathrm{H}\right] \mathrm{Ins}(1,2,3,4,6) P_{5}$ hydroxy kinase, $2752 \pm 93$ d.p.m. into $\left[{ }^{3} \mathrm{H}\right] \operatorname{Ins} P_{6}$ in $30 \mathrm{~min} ; \mathrm{D}-\left[{ }^{3} \mathrm{H}\right] \operatorname{Ins}(1,2,4,5,6) P_{5}$ hydroxy kinase, $2020 \pm 37$ d.p.m.; [ $\left.{ }^{3} \mathrm{H}\right] \operatorname{Ins}(1,3,4,5,6) P_{5}$ hydroxy kinase, $2966 \pm 178$ d.p.m. (all of the $\left[{ }^{3} \mathrm{H}\right] \mathrm{Ins} P_{5}$ s possessed specific radioactivities of approx. $60 \mathrm{Ci} / \mathrm{mmol}$ ). The marker enzymes cyclic AMP phosphodiesterase and glycogen phosphorylase were assayed in duplicate on two completely independent batches of amoebae (one of which yielded the Ins $P_{6}$ data and one of which gave all the lysates which were assayed for $\left[{ }^{3} \mathrm{H}\right] \mathrm{Ins} P_{5}$ hydroxy kinase). The data were pooled and are presented as means \pm S.E.M. $(n=4)$.

which had been introduced into the original acid extract. Although the marker enzymes and morphology of the slimemould cultures went through the changes characteristic of normal differentiation and there was an appreciable alteration of the three $\left[{ }^{3} \mathrm{H}\right] \operatorname{Ins} P_{5}$ hydroxy kinase activities, the levels of $\operatorname{Ins} P_{6}$ only rose marginally (see Fig. 13).

\section{DISCUSSION}

Of the six possible Ins $P_{5}$ isomers, at least five have been found in extracts prepared from a variety of cells. Dictyostelium extracts contained relatively similar concentrations of $\operatorname{Ins}(1,2,3,4,6) P_{5}$,
Ins $(1,3,4,5,6) P_{5}$ and $\mathrm{D}-\mathrm{Ins}(1,2,4,5,6) P_{5} \quad(8-36 \mu \mathrm{M}$; Stephens \& Irvine, 1990; see the Results section); HL60 and NG115-401L C3 cell extracts contained Ins $(1,3,4,5,6) P_{5}$ in a substantial excess ( $>100$-fold) over other Ins $P_{5}$ species; and germinating mungbean extracts contained readily detectable amounts of $\mathrm{D}$ - and $\mathrm{L}$ Ins $(1,2,4,5,6) P_{5}$ (predominantly L-; see above) and D- and/or LIns $(1,2,3,4,5) P_{5}$. Clearly, a simple universal pattern of the relative abundance of Ins $P_{5}$ isomers in cells is not emerging, although all these cell and tissue types contain substantial amounts of Ins $P_{6}$. The reasons for the differences are unclear. There are huge phylogenetic differences between these different cell and tissue types, and also the germinating mung beans are unique among the group of cells studied in that they are in the process of rapidly dephosphorylating net amounts of $\operatorname{Ins} P_{6}$ (in at least one tissue compartment). One possible interpretation of the results is that there is a pattern which reflects the metabolism of $\operatorname{Ins} P_{6}$ (i.e. the accumulation of relatively large amounts of $\operatorname{Ins} P_{6}$ together with much lower levels of the Ins $P_{5}$ isomers involved in Ins $P_{6}$ biosynthesis and degradation), and within mammalian cells there is in addition the superimposition of an accumulation of one specific isomer of $\operatorname{Ins} P_{5}$, Ins $(1,3,4,5,6) P_{5}$. Such an interpretation would place emphasis on searching for possible distinct physiological functions for $\operatorname{Ins} P_{6}$ and $\operatorname{Ins}(1,3,4,5,6) P_{5}$.

A survey of the Ins $P_{5}$ hydroxy kinase activities in several different tissues also revealed a range of patterns. S. Biswas et al. (1978) have previously detected an enzyme with $\operatorname{Ins}(1,3,4,5,6) P_{5}$ hydroxy kinase activity in highly purified fractions of mung beans (they would have considered it a consequence of an ADP: Ins $P_{6}$ phosphotransferase operating in reverse). The data described above, obtained by an assay involving crude cytosolic fractions, suggest that, although other Ins $P_{5}$ hydroxy kinase activities can also be detected in mung-bean supernatants, Ins $(1,3,4,5,6) P_{5}$ hydroxy kinase is the most active. The fact that $\left[{ }^{3} \mathrm{H}\right]-$ or $\left[{ }^{32} \mathrm{P}\right]-$ Ins $(1,3,4,5,6) P_{5}$ could not be detected in radiolabelled mung beans presumably means that its concentration is relatively low, and this would be consistent with the major Ins $P_{5}$ isomer [ $\mathrm{L}$-Ins $(1,2,4,5,6) P_{5}$ ] detected in these preparations being a member of the pair of $\left[{ }^{3} \mathrm{H}\right] \mathrm{Ins} P_{5} \mathrm{~s}$ that are least readily phosphorylated and therefore a prime candidate for membership of the pathway by which Ins $P_{6}$ is dephosphorylated.

Dictyostelium amoebae contained Ins $P_{5}$ hydroxy kinase activities capable of phosphorylating all three of their endogenous $\operatorname{Ins} P_{5}$ s, D-Ins $(1,2,4,5,6) P_{5}$, Ins $(1,3,4,5,6) P_{5}$ and $\operatorname{Ins}(1,2,3,4,6) P_{5}$, but not the three other Ins $P_{5}$ s (Stephens \& Irvine, 1990; see above). However, only Ins $(1,3,4,5,6) P_{5}$ may act as a precursor in the synthesis of Ins $P_{6}$ de novo, because, unlike both of the other Ins $P_{5} \mathrm{~s}$, which are largely formed by dephosphorylation of $\operatorname{Ins} P_{6}$, it is the product of a series of five soluble myo-inositol and myoinositol phosphate hydroxy kinase activities (Stephens \& Irvine, 1990). Thus, of the two Ins $P_{5}$ hydroxy kinase activities resolved in amoebae, one catalyses the phosphorylation of the $\operatorname{Ins} P_{5}$ involved in synthesis of $\operatorname{Ins} P_{6}$ de novo and the other catalyses the phosphorylation of the two Ins $P_{5} s$ involved in potential futile cycling of the phosphates at the 3- and 5-positions of Ins $P_{\mathrm{e}}$. The intracellular concentration of $\operatorname{Ins} P_{6}$ in amoebae $(0.6 \mathrm{~mm}$; Stephens \& Irvine, 1990) is sufficient to cause substantial $(80-90 \%)$ inhibition of all three Ins $P_{5}$ hydroxy kinase activities, suggesting that these enzymes' potential to make Ins $P_{6}$ in vivo is being substantially restrained by the levels of their product. This repressed capacity to manufacture $\operatorname{Ins} P_{6}$ could be readily expressed if the levels of $\operatorname{Ins} P_{6}$ were to fall and would therefore represent a buffering mechanism tending to hold $\operatorname{Ins} P_{6}$ levels constant. Such a stabilizing effect of this pattern of product inhibition might explain the lack of change in $\operatorname{Ins} P_{6}$ levels that occurs through the full developmental cycle of Dictyostelium. However, it should be emphasized that the assays on which the 
effects of Ins $P_{6}$ on the $\operatorname{Ins} P_{5}$ hydroxy kinase activities were seen were determined in vitro, and because the ionic form of Ins $P_{6}$ in intact cells is unknown (and very probably both complex and critical to its properties) it is not clear that the $\operatorname{Ins} P_{5}$ hydroxy kinase activities would experience the same braking effect as that which would be expected from the assays in vitro. Nevertheless, given the profound changes that occur in cellular physiology and structure during the complete life cycle of Dictyostelium, it is a remarkable manifestation of the mechanisms responsible for Ins $P_{6}$ homoeostasis in this organism that such an even level of Ins $P_{6}$ is maintained throughout the entire process (Fig. 13).

In rat brain there are at least five $\operatorname{Ins} P_{5}$ hydroxy kinase activities, although we do not yet know how many distinct enzymes are involved. The initial rate of conversion of $\left[{ }^{3} \mathrm{H}\right] \operatorname{Ins}(1,3,4,5,6) P_{5}$ into $\left[{ }^{3} \mathrm{H}\right] \operatorname{Ins} P_{6}$ is significantly smaller than for the other $\left[{ }^{3} \mathrm{H}\right]$ Ins $P_{5}$ hydroxy kinase activities. It is possible that the phosphorylation of $\left[{ }^{3} \mathrm{H}\right] \operatorname{Ins}(1,3,4,5,6) P_{5}$ is severely limited by the presence of significant quantities of endogenous Ins $(1,3,4,5,6) P_{5}$ in the tissue. In this regard, the sole study of the Ins $P_{5}$ s that could be extracted from a mammalian brain only detected Ins $(1,3,4,5,6) P_{5}$, although this was with calf brains some time post mortem; the brains had been purchased from a local supermarket (Phillippy \& Bland, 1988). We would predict, on the basis of the present results from mammalian cell lines, that $\operatorname{Ins}(1,3,4,5,6) P_{5}$ would also be the major $\operatorname{Ins} P_{5}$ isomer in rat brain in vivo.

The number of different Ins $P_{5}$ isomers and Ins $P_{5}$ hydroxy kinase activities detected in cell extracts is somewhat bewildering. If these activities are an accurate representation of the routes of metabolism of $\operatorname{Ins} P_{5} \mathrm{~s}$ and $\operatorname{Ins} P_{6}$ in intact cells, then these compounds are members of a metabolic network far more extensive and intricate than we had previously imagined and for which the physiological functions still remain obscure.

P.T.H. is a Lister Institute Research Fellow. D. R.P. is funded by a grant from Celltech plc U.K. A.F.S. is funded by a grant from Upjohn Corp. M.R.H. is a recipient of a Research Award from the ILSI Research Foundation. L.R.S. is a Babraham Research Fellow. P.T.H. and M.R.H. also thank Perstorp Pharma for financial support.

\section{REFERENCES}

Baginski, E. S., Zak, B. \& Foq, P. P. (1967) Clin. Chem. 13, 326-330 Bartlett, G. R. (1959) J. Biol. Chem. 234, 466-468

Bartlett, G. R. (1982) Anal. Biochem. 124, 425-431

Biswas, B. B., Biswas, S., Chakrabarti, S. \& De, B. P. (1978) in Cyclitols and Phosphoinositides (Wells, W. W. \& Eisenberg, F., eds.), pp. 57-68, Academic Press, New York

Biswas, S. \& Biswas, B. B. (1965) Biochim. Biophys. Acta 108, 710-713
Biswas, S., Maity, I. B., Chakrabarti, S. \& Biswas, B. B. (1978) Arch Biochem. Biophys. 185, 557-566

Bradford, M. R. (1976) Anal. Biochem. 72, 248-254

Cerdan, S., Hansen, C. A., Johanson, R., Inubishi, T. \& Williamson, J. R. (1986) J. Biol. Chem. 261, 14676-14680

Cosgrove, D. J. (1969) Ann. N.Y. Acad. Sci. 165, 677-686

Cosgrove, D. J. (1980) Inositol Phosphates, Their Chemistry, Biochemistry and Physiology, Elsevier, Amsterdam

Das, O. P. \& Henderson, E. J. (1983) Biochim. Biophys. Acta 736, 45-56

French, P. J., Bunce, C. M., Brown, G., Creba, J. A. \& Michell, R. H. (1988) Biochem. Soc. Trans. 16, 985-986

Galliard, J., Michell, R. H. \& Hawthorne, J. N. (1965) Biochim. Biophys. Acta 106, 551-563

Hawkins, P. T., Reynolds, D. J. M., Poyner, D. R. \& Hanley, M. R. (1990) Biochem. Biophys. Res. Commun. 167, 819-827

Hughes, P. J. \& Shears, S. B. (1990) J. Biol. Chem. 265, 9869-9875

Irving, G. C. J. \& Cosgrove, D. J. (1972) J. Bacteriol. 112, 434-438

Jackson, T. R., Hallam, T. J., Downes, C. P. \& Hanley, M. R. (1987) EMBO J. 6, 49-54

Ji, H., Sandberg, K., Baukal, A. J. \& Catt, K. J. (1990) J. Biol. Chem. 264, 20185-20188

Johnson, L. F. \& Tate, M. E. (1969) Can J. Chem. 47, 63-73

Kay, R. R. (1979) J. Embryol. Exp. Morphol. 52, 171-182

Kay, R. R. \& Trevan, D. J. (1981) J. Embryol. Exp. Morphol. 62, 369-378

Koppitz, B., Vogel, F. \& Mayr, G. W. (1986) Eur. J. Biochem. 161, $421-433$

Lim, P. E. \& Tate, M. E. (1973) Biochim. Biophys. Acta 302, 316-328

Mayr, G. W. (1988) Biochem. J. 254, 585-591

Mayr, G. W. \& Dietrich, W. (1987) FEBS Lett. 213, 278-282

Phillippy, B. Q. \& Bland, J. M. (1988) Anal. Biochem. 175, 162-166

Phillippy, B. Q., White, K. D., Johnston, M. R., Tao, S. H. \& Fox, M. R. S. (1987) Anal. Biochem. 162, 115-121

Radenberg, T., Scholz, P., Bergmann, G. \& Mayr, G. W. (1989) Biochem. J. 264, 323-333

Sharpes, E. S. \& McCarl, R. L. (1982) Anal. Biochem. 124, 421-424

Stephens, L. R. (1990) in Methods of Inositide Research (Irvine, R. F., ed.), pp. 9-30, Raven Press, New York

Stephens, L. R. \& Downes, C. P. (1990) Biochem. J. 265, 435-452

Stephens, L. R. \& Irvine, R. F. (1990) Nature (London) 346, 580-583

Stephens, L. R., Hawkins, P. T., Carter, A. N., Chahwala, S. B., Morris, A. J., Whetton, A. D. \& Downes, C. P. (1988a) Biochem. J. 249, 271-282

Stephens, L. R., Hawkins, P. T., Barker, C. J. \& Downes, C. P. (1988b) Biochem. J. 253, 721-733

Stephens, L. R., Hawkins, P. T. \& Downes, C. P. (1989) Biochem. J. 262 , 727-737

Stephens, L. R., Kay, R. R. \& Irvine, R. F. (1990) Biochem. J. 272, 201-210

Tomlinson, R. V. \& Ballou, C. E. (1961) Biochemistry 1, 166-171

Vallejo, M., Jackson, T., Lightman, S. \& Hanley, M. R. (1987) Nature (London) 330, 656-658

Watts, D. J. \& Ashworth, J. M. (1970) Biochem. J. 119, 171-174

Williams, S. G. (1970) Plant Physiol. 45, 376-381

Zuiderweg, E. R. P., Van Beek, G. G. M. \& De Bruin, S. H. (1979) Eur. J. Biochem. 94, 297-306 